Boise State University

ScholarWorks

Geosciences Faculty Publications and

Presentations

Department of Geosciences

$12-2015$

\title{
Natural Degradation of Earthworks, Trenches, Walls and Moats, Northern Thailand
}

Spencer H. Wood

Boise State University

Layle R. Wood

Alan D. Ziegler

National University of Singapore

This is an author-produced, peer-reviewed version of this article. The final, definitive version of this document can be found online at Journal of Field Archaeology, published by Maney Publishing. Copyright restrictions may apply. doi: $10.1080 / 00934690.2015 .1103645$ 


\title{
Natural Degradation of Earthworks, Trenches, Walls and Moats, Northern Thailand
}

\author{
Spencer H. Wood \\ Geosciences \\ Boise State University \\ Boise, Idaho \\ swood@boisestate.edu \\ Layle R. Wood \\ Boise, ID
}

\author{
Alan D. Ziegler \\ Geography Department \\ National University of Singapore \\ Singapore
}

"...........structures of this kind are hidden away securely under the thick overgrowth:

thus does nature preserve what man would surely destroy" (from Sumet Jumsai, 1970)

\begin{abstract}
We investigate the geometry, age, and history of several enigmatic northern Thailand earthwork entrenchments that are mostly located on hills and could not have held water to form moats. The earthworks are either oval or rectangular in map view; and they typically encircle 0.3 -to-1-km² areas that do not have potsherd debris indicative of former towns. Most trenches are 3-5 m deep with inner walls 4.5-8 $\mathrm{m}$ high. Some encircling earthworks are concentric double trenches spaced approximately $10 \mathrm{~m}$ apart. Historians have suggested these earthworks enclosed defensible areas where people in outlying villages sought refuge when under attack by neighboring rulers, the Chinese Ho, or the Burmese. We believe that some encircling entrenchments may have been for the capture or containment of elephants. Nearly all of the once near-vertical original walls have degraded to slopes of $32-47^{\circ}$. Fitting calculated curves of the diffusion-based scarp-degradation model to our height-slope data, and assuming most scarps have degraded since the end of La Na Kingdom time A.D. 1558. We derive a diffusion coefficient of $0.002 \mathrm{~m}^{2} \mathrm{y}^{-1}$. Slopes of the rectangular earthwork at Souvannkhomkham, Laos, across the Mekong River from Chiang Saen Noi, are significantly more degraded (approximately $32^{\circ}$ ), indicating an age of 800-1200 years. Locations of these earthworks are established in hope that they will be preserved as part of the Thai and Lao archaeological legacy.
\end{abstract}

Keywords: earthworks, slope degradation, Lan Na Kingdom, Chiang Saen, $14^{\text {th }}$ century, elephants

\section{Introduction}

Ruins of brick and stone religious monuments, brick city walls, and earthworks and moats are the enduring relics of northern Thailand's early kingdoms. This paper focuses on enigmatic earthwork trench systems encircling areas of $<1$ $\mathrm{km}^{2}$, some of which are built on hillsides and could not possibly hold water, and therefore are not former moats. The earthworks, originally recognized on aerial photos, are now easily observed on Google Earth images (TABLE 1). Many trench systems do not encircle areas of sherds and brick debris, as would be expected of defensive earthworks encircling ancient towns. The earthwork entrenchments are typically circular-although some are rectangular-are built across gentle hillslopes, and form enclosures. The entrenchments are typically greater than $3 \mathrm{~m}$ deep. Some historians have suggested the earthworks were defensible structures, but we argue below that some may have also had other purposes, such as the capture and containment of elephants. In this study we did not attempt to excavate or date 
materials of the earthworks, although optically stimulated luminescence dating of excavated materials would establish (at greater expense) a more precise chronology. Instead we analyze the extent of slope degradation on several of these features to better understand the process of slope reduction over time and as a method to estimate their age in the context of Thai history.

Listed in TABLE 1 are locations of the earthworks we surveyed, and several unsurveyed locations recently reported to us and confirmed by viewing them on Google Earth. We document the location and characteristics of these features in hope that they will be preserved as sites of interest to tourism and archaeological heritage (cf. Jumsai 1970; Supajanya and Villibhotma 1972).

[Table 1]

\section{Historical Background}

Earthen walls and moats (i.e. water-filled) encircling larger towns are typical of prehistoric Iron-Age (younger than 500 B.C.) and Dvaravati settlements in central and northeastern Thailand (Parry 1992; Boyd et al. 1999a, 1999b; O'Reilly 2001, Higham 2002, Higham and Thosarat, 2012). The Hindu-Buddhist Dvaravati Culture ( A.D. 6001000 ) is considered the earliest historical culture in Thailand (Glover, 2010). No Dvaravati towns are known in northern Thailand, except Haripunchai at Lamphun, which was founded before the $10^{\text {th }}$ century A.D. (Ongsakul 2005). The only well studied pre-La Na site is the Iron-Age cemetery near Lamphun believed to contain remains 500 B.C. - A.D. 200 and overlain by a layer with a radiocarbon date on burnt bone of $1490 \pm 50$ B.P. 71 (CAL A.D. 429657) (Pautreau et al. 2003: 5).

Buddhist monks began writing chronicles as palm-leaf manuscripts in the early $16^{\text {th }}$ Century (Penth 1994). Many were written in Pali, translated and recopied many times into archaic Thai script and language. Scholars translating these chronicles into western languages discuss at length problems with authenticity and chronology (Notton 1926; Penth 1994; Wyatt and Wichienkeeo 1998). The chronicle accounts mention towns in the vicinity of present day Chiang Saen and at Mae Sai, both in Chiang Rai Province (Onsakul 2005: 19-21; Unchaijin, 2012). Chronicles of China and Southeast Asia relate legends of early Thai people migrating from southern Yunnan and establishing kingdoms in the area before A.D. 700 (Wyatt 2003; Onsakul 2005). An early city and kingdom called Wiang Yonok is described in the Sinhanavati Chronicle (Notton 1926) and the chronicles date its founding to about the $1^{\text {st }}$ century A.D. (Onsakul 2005: 19). The Chiang Mai Chronicle relates a history of rulers of the region starting with King Lawacangkarat in A.D. 639 , and a succession of 24 rulers ending with the birth of King Mangrai in A.D. 1238, founder of the Lan Na dynasty (Wyatt and Wichienkeeo 1998).

During the Lan Na dynasty (A.D.1296-1558) many towns were formed with earthen walls; and most brick Buddhist monuments and brick city walls were constructed during this time. Hostilities occurred among local rulers, as well as conflict with the Chinese Ho and with the Burmese in the latter part of Lan Na time. The region fell under Burmese rule in A.D. 1558. The various city-states at times asserted their independence, and fought the Burmese occupiers. Thai forces finally liberated Chiang Mai from the Burmese in 1775; Chiang Saen, in 1804. Chiang Rai was reestablished in 1844, and the size of the walled town approximately doubled (Penth 2004). Chiang Saen was deserted after defeat of the Burmese, and the old city abandoned. It was found in ruins when visited by the Garnier expedition in the spring of 1867 (Garnier 1885). Le May (1926) saw the city abandoned and covered with vegetation in 1913. Construction of the modern city of Chiang Saen and restoration of Buddhist monuments has been ongoing since about 1950 (Lertrit 2000).

\section{Previous Work on Similar Earthworks in Southeast Asia}

Earthworks encircling villages in southeast Asia have been known to archaeologists for many years. The best known are Iron Age moats (i.e. water filled) encircling mounds in the Mun and Chi River basins (FIG. 1) (Boyd et al. 1999a, 1999b; Parry 1992; Higham 2012: 186-189) and the Dvaravati-age towns of central and northeast Thailand (Higham, 2002: 255-259). Most were fed by streams and had the dual purpose of water management, as well as a defensive structure for a village. 
Dega (1999) describes concentric earthen embankments in eastern Cambodia enclosing a 220-m diameter area (1.7 ha), and surrounded by a trench on average $22-\mathrm{m}$ wide and $2.5-\mathrm{m}$ deep, with an outer wall rising an additional 2 meters (i.e. the descent from outside into the trench is $\sim 4.5 \mathrm{~m}$ ). The earthworks have a wide entryway $(>20-\mathrm{m})$ that is graded down to the outer terrain and the inner platform. Dega (1999) makes the point that the trenches are not moats, nor do they appear to convey or store water. The enclosed sites contain abundant late Neolithic stone tools and sherds of low-fired, chord- marked, or other incised motif pottery, indicating that the sites were villages. Lack of metal artifacts led Dega (1999) to suggest the sites may be older than 1000 B.C.

According to Ongsakul (2005), northern Thai towns located on river floodplains and surrounded by earthen walls and moats are characteristic of the Hariphunchai Period. Hariphunchai settlements began as northern extensions of the Dvaravati culture of the central plain around A.D. 867. Indigenous Lawa People lived in the surrounding mountains. Both "conch-shaped" and rectangular outlines of towns are found in the southern Chiang Mai basin. Later Hariphunchai towns had a more geometric rectangular form and were surrounded by two earth walls divided by a moat that was used as a reservoir (Onsakul, 2005: 37). Onsakul (2005: 36.) writes that "In the event of an invasion (near a town) people who lived scattered outside the town would gather within its walls".

The chronicles relating history of the Lan Na dynasty ( 1261-1558 A.D.) indicate the initial founding of a typical town involved construction of a moat and earthen walls. Towns of the established Lan Na kingdoms eventually had imposing brick walls, but it is not clear from the chronicles when the original brick walls of Lamphun, Chiang Mai, Chiang Rai, Fang, Chiang Khong, and Chiang Saen were constructed (locations are shown in FIG. 1, 2). It is believed that the mud walls at Chiang Saen were stabilized by brick during the reign of King Sam Fang Kaen (1401-1442 A.D.) to fend off attacks by the Burmese and the Ho soldiers and bandits from southern China at the time (Chaisano 1987; Lertrit 2000). In a later discussion of the Chiang Saen wall we discuss new thermoluminescence ages on brick from the wall. The chronicle states that bricks were made for the Chiang Mai city wall in 1517-18 A.D. (Wyatt and Wichienkeeo 1998:110).

Supajanya and Vallibhotama (1972) noted that the encircling earthworks in northern Thailand differ from those of the Mun and Chi River basins. The earthworks are typically found on small hills, and have irregular shapes guided by the topography. They also noted the lack of potsherds and other artifacts that would have indicated a long period of occupation. They suggested these features were fort towns in which people came to stay in time of war. They emphasized the importance of identifying these features as well as their preservation. They listed earthworks at Phrao, Wieng Manora (near Phrao) and Mae Chi (Phan District) as having two or three ring-shaped plans. Subsequently, Supajanya and Vanasin (1986) inventoried (from air photos) ancient settlement evidence of the Mun and Chi River basins. A map from a report by Thiva Supajanya (date unknown) of the Ruak, Kum, and Mae Chaen River basins, quoted by Shinawatra (2007), shows a number of locations of ancient settlements (FIG. 2). In addition, an earthen-moat-and-wall structure 4-m high at Thoen is described by Jumsai (1970). Other ancient settlements are briefly described by Onsakul (2005).

A photograph of the Phrao trench system appears in the 2004 edition of "A Brief History of Lan Na", in which Hans Penth called it an "old type of Thai Yuan settlement: the former city (wiang) of Phrao with triple earth rampart". The system consisted of two compartments, interconnected by two parallel earth walls, and was probably constructed around 1300-1350 A.D. The site is located on a hill called "San Wiang", but it is presently uninhabited, except for the Wat Jao Lan Thong constructed in 1935 A.D. (Penth 1972). "Wat" means a temple in Thai language. The term "Thai Yuan" refers to the Thai- speaking people who came from the Yunnan region and settled into this area many centuries before the La Na Period (Onsakul, 2005: 21).

[FIG.s 1,2,]

\section{Methods}

From 2010 to 2012 we examined the sites in the field and surveyed elevation profiles across 9 of the earthwork entrenchments (FIGS 3-9 and Table 1). Many of the earthworks were originally identified using 1986 stereo airphotos. Now these features are easily seen on Google Earth images. Besides the enigmatic earthworks on hills, we also profiled the degraded city wall and moat of Chiang Saen, prior to its current reconstruction. Earthworks at Chiang Saen Noi and Sop Ruak surround known Lan Na towns containing brick Buddhist monastery and temple ruins of the $13-16^{\text {th }}$ century A.D. We also report on examined and profiled the rectangular earthwork across the river 
in Laos which contains similar brick ruins in its interior. Enlarged 1:50,000 scale Thai topographic maps were used in combination with field plotting of features by their UTM (universal transverse mercator) coordinates obtained with handheld Garmin Vista HCX GPS receivers. Older topographic maps use the India-Thailand UTM Grid, while newer maps use WGS-84 UTM grid (identified on our figure captions). In many situations the outline of the entrenchments on the images can be traced directly onto the topographic map from the Google image using roads and streams for referencing.

Our examination on foot,noted presence or absence of potsherds or bricks within or just outside the encircling earthworks. The surface of the area enclosed or just outside of most earthworks has been ploughed and cultivated in recent time. Our survey for bricks and potsherds of the interior areas consisted of 3 or 4 traverses across the breadth of the interior looking at barren ploughed ground or cuts into the soil profile. We only noted presence of sherds, or their total absence, and did not systematically count number of sherds per area, because they were so rare and were undecorated. Profiling was done using a hand-held inexpensive carpenter's slope indicator ( $\pm 1^{\circ}$ precision) and a $2-\mathrm{m}$ bamboo rod, laid upon the slope end to end. Care was taken to avoid profiles where earthworks have been graded or modified by agricultural activity. The trigonometry of slope distance and the angle of each measurement was determined for horizontal distance and elevation change, and then cumulatively summed for horizontal and vertical coordinate points along the profile. For steep slopes $\left(45^{\circ}\right)$, the error of $\pm 1^{\circ}$ for the $2-\mathrm{m}$ rod length is $\pm 2.5 \mathrm{~cm}$. We believe the errors are self-cancelling as the angle is randomly over-read and under-read. The estimated accuracy of distance and height of profiles is $\pm 0.2 \mathrm{~m}$. This method obtains accurate mid-slope angles that can be used to estimate a relative age based on degradation of the slope since it was originally excavated (Bucknam and Anderson 1979; Nash 1980; Colman and Watson 1983).

To estimate the relative age of the earthworks we applied a diffusion-based approach that takes into consideration degradation of walls of the works over time (see Appendix). The principal equation for this calculation is the following (Equation A7 in the Appendix):

$\left.\theta \mathrm{m}=\arctan \left[\left(4 \pi \mathrm{k} \tau / \mathrm{h}^{2}\right)-\cot ^{2} \theta 0\right)\right]^{-1 / 2}$

where $\theta 0$ is the initial slope angle of the scarp (assumed to be the angle of repose, or $50^{\circ}$ for the study areas (see Appendix); $\theta \mathrm{m}$ is the measured mid-slope angle; $\mathrm{k}$ is the diffusion coefficient $\left(\mathrm{m}^{3} \mathrm{~m}^{-1} \mathrm{y}^{-1}\right) ; \tau$ is the time interval over which the slope angle diminishes as a diffusion process; and $\mathrm{h}$ is the height of the scarp or face of the earthwork. The equation produces a set of curves from measurement data than can be used to calibrate $\mathrm{k}$ for a feature of known age, and then to infer ages from height-slope data on features with significantly different age. We refer the reader to the Appendix for details.

(FIG. 3).

\section{Descriptions of Earthworks}

\section{Earthen Trench at Ban Nong Pung}

A single earthen trench encircles a $0.31-\mathrm{km}^{2}$ area on a hill east of Ban Nong Pung ("Ban" means village in Thai language) in Chiang Rai province, $11 \mathrm{~km}$ east of Mae Chan (FIG. 2, 3). The trench intersects a second oval-shaped trench system to the north that encircles a smaller area of the village of Ban Kiu Phrao (FIG. 3). The Ban Kiu Phrao earthwork is clearly a moat, but the Ban Nong Pung trench climbs a hill with relief of 30 meters, and cannot hold water. The Ban Nong Pung trench is $6 \mathrm{~m}$ deep and $12 \mathrm{~m}$ wide, with an inner trench wall $9 \mathrm{~m}$ high (FIG. 4a ,4b). A roadway cut to the level of the bottom of the trench, passing through the southeast side, appears to have been a gate into the protected area, or a path for elephants. At the northeast side is a low $150-\mathrm{m}$ wide swale that is flooded by the Nong Kheo Reservoir, apparently a low and marshy area into which the trench was not extended. A preliminary search of the surrounded hill did not reveal any broken bricks or pottery. It therefore appears that the southern trench did not surround a village. The area within the northern Ban Kiu Phrao trench is a modern village, thus the presence or absence of historical artifacts cannot be easily verified.

[FIG. 3] 


\section{The Double-Trench System Near Phrao}

Three kilometers west of the town of Phrao in Chiang Mai Province (FIG. 1) are two earthen trench systems that encircle a hill that rises $25 \mathrm{~m}$ above the flat valley bottom. The hill is called San Wiang by the local people (Penth 1972; 2004). The northern entrenchment consists of an inner and outer trench and encloses an area of $0.13 \mathrm{~km}^{2}$ (FIG. 5). Assuming the original trenches had vertical walls and have eroded to their present slopes of 35 to $43^{\circ}$, the original dimension of the inner trench was $9 \mathrm{~m}$ wide and $5 \mathrm{~m}$ deep, the outer trench $5.5 \mathrm{~m}$ wide and $2 \mathrm{~m}$ deep; and the intervening divide was $5 \mathrm{~m}$ wide (FIG. $4 \mathrm{c}$ and $4 \mathrm{~d}$ ). It is puzzling whether a substantial rammed earthen wall ever existed at this site. Discontinuous mounds $1 \mathrm{~m}$ high occur along the inside of the inner trench, but there is no obvious construct of spoils from the excavation.

On the west side of the hill, a single 4-m deep trench, $100 \mathrm{~m}$ long, runs to another double-trench system to the south (FIG. 5); however, it does not connect at grade, and does not appear to be for water conveyance. The southern double-trench system is partly obliterated by road grading and a village, but remnant segments are of a similar double trench system 3 to $4 \mathrm{~m}$ deep. A few potsherds were noted along the northern rim and in the vicinity of Wat Phrao Chao Lan Thong. The sherds are unglazed and have no distinctive shape or decoration. Near the wat are abundant broken brick and roof-tile debris of an earlier Lan Na age temple. The temple contains a bronze Buddha image inscribed with a date equivalent to A.D. 1525. Penth (1972) mistakenly called the earthworks a "triple earthen rampart". Today, the feature that appeared to be the third wall is a divide between two trenches, without any trace of construction (FIG. 3, 4d).

[FIG. 4] [FIG. 5]

\section{The Single Trench System at Ban Huai Wiang Hai}

Several intersecting ovoid and circular entrenchments encircle hills near Ban Huai Wiang Wai, $2 \mathrm{~km}$ east of Mae Chan, Chiang Rai Province (FIG. 2, 6). The northern, central, and southern enclosures each encircle areas of about $0.3 \mathrm{~km}^{2}$ (Table 1). Much of the earthwork system has been modified by agricultural development. However, we were able to profile a section on the northernmost structure that appeared unaltered. The single trench is $3.5 \mathrm{~m}$ deep and the inner wall of the trench is $7.5 \mathrm{~m}$ high (FIG. 6): the upper $1.5 \mathrm{~m}$ appear to be piled-up spoils. The sloping floor of the trench could not have held water. Area was not fully examined for potsherds, but none were noted.

[FIG. 6]

\section{The Double-Trench System Near Wat Phraison Kiri}

A double-trench, oval-shaped system encloses a $0.41-\mathrm{km}^{2}$ area, on a hill, $1 \mathrm{~km}$ southwest of Wat Praison Kiri, $12 \mathrm{~km}$ east of Mae Chan, Chiang Rai Province (FIG. 2, 4e, 7). The entrenchment lies upon a hillside with $50 \mathrm{~m}$ of relief, and could not have held water as a moat (FIG. 7). The interior was thoroughly searched for indications of a former village, but broken bricks or pottery are nonexistent. We believe this site was never an area of permanent habitation.

The inner trench is $12-\mathrm{m}$ wide, with a $7.5 \mathrm{~m}$ high inner wall, assuming that the original walls were excavated vertically. The flat-topped separation ridge between the inner and outer trench is $14 \mathrm{~m}$ wide (FIG. 4e and 7). At the north end of the system is a gap in the double trenches. The gap is a swale with a flat bottom $100 \mathrm{~m}$ wide; it is currently a rice paddy. The east side of the swale is a north-south oriented trench. This perpendicularly-oriented and truncating trench is $4 \mathrm{~m}$ deep, $10 \mathrm{~m}$ wide, and $37 \mathrm{~m}$ long, with a $4-\mathrm{m}$ berm ridge on the west side. Water springs seep into the lower part of this swale, so the enclosure did have an accessible small water supply, but it was too low to fill the trench.

The double-trench system is again interrupted by a smaller entrenchment (shown by a dashed line on FIG. 7 map, and Profile A. This encirclement encloses a $0.06-\mathrm{km}^{2}$ area with a trench $5 \mathrm{~m}$ wide and $2 \mathrm{~m}$ deep (FIG. 7). The south end of the double-trench system has been partly obliterated by excavation and leveling for a rubber tree plantation, exposing barren bedrock of medium-crystalline black diorite.

[FIG. 7] 


\section{Earthen Trench at Souvannakhomkham, Laos}

In Bokeo Province of Laos, across the Mekong River from the ancient Thai town of Chiang Saen Noi is a rectangular earthwork entrenchment roughly $2 \mathrm{~km}$ by $0.5 \mathrm{~km}$, with an open side along the river (FIG. 2, 8). The earthwork runs up a 40-m high hill at its northwest corner (FIG. 8, 9a). This section of the earthwork could not have contained water. The trench is $3 \mathrm{~m}$ deep in places. The bottom of the trench is $14 \mathrm{~m}$ wide (FIG. 9a). Within the enclosed area are the ruins of only two brick Lan Na style monuments, whereas at least 20 sites of brick monuments are located outside the enclosure. The area of concentration of ruined stupas, temples, and Buddha statues (FIG. 9b, 9c) to the east along the river is called Souvannakhomkham by Lao people. We surveyed locations of these ruins in 2008 when hillsides and fields had been burned and cleared for rainy season planting allowing for a view of the trench (FIG.9a). When profiled in 2012, the entire area had been converted to banana plantations. Riverbank construction had partially disturbed at least one temple site.

Many of the Thai chronicles indicate an ancient city near the mouth of the Kok River. This legendary city, which preceded the founding of Chiang Saen, was named Meuang Suwanakhomkham (Ongsakul 2005; Rattanavong 2006; Shinawatra 2007: 41). Little or no archaeological study has been done of this area in Laos. All of the ruins near the mouth of the Kok River, and across the Mekong in Laos appear to be of Lan Na style. This area may have been an extension of, or a part of Chiang Sean and/or Chiang Saen Noi, and not the earlier city according to Lorrillard (2000). However, the slopes of this earthwork are the shallowest $\left(29-32^{\circ}\right)$ of those examined in this study, suggesting to us an age of the trench older than Lan Na time (discussed below).

Only a part of this earthwork could have held water. Its shape and position among the temple ruins indicate it was built for defensive purposes. Like the Chiang Saen Noi earthwork, this earthwork at Souvannakhomkham extends to the bank of the Mekong River. The river bank is $10 \mathrm{~m}$ high at low water in the dry season. Apparently the offensive invaders were not expected to attack from boats, and if they did, the 5-to-10-m high river bank (during dry season) would have been an effective defensive impediment. Access from boats on the river was most likely as it is today: steps cut into the silt banks. The steps provide a stairway at strategic access points that could be easily defended.

[FIG. 8, 9]

\section{The Entrenchment Around Chiang Saen Noi}

A half-circle earthen entrenchment about 1-km diameter encloses much of the old site of Chiang Saen Noi (an area of about $0.62 \mathrm{~km}^{2}$ ) on the south bank of the Mekong River in Chiang Rai Province (FIG. 2, 8). Where preserved on its west side, it is 4 to $5 \mathrm{~m}$ deep, and $15 \mathrm{~m}$ wide (FIG. 8). The east end of the trench has been partially filled with Mekong River flood sediment. A charcoal piece from sediment 5 meters deep near the bottom of the infilled trench gave an AMS radiocarbon age of CAL A.D. $1475 \pm 38$ (UGA: 12230) (Wood et al. 2008). According to the Jinakalamali Chronicle, the city was founded A.D. 1327, two years before the city of Chiang Saen (Penth 1994). It is believed to have been a temporary camp site for Phaya Saen Phu, as he was constructing the walled city of Chiang Saen (Chinnakarn Maleepakorn Chronicle, cited by The $8^{\text {th }}$ Regional Office of Fine Arts (2006). Temple ruins within the earthwork indicate it was an important village in Lan Na time.

\section{The Entrenchment at Sop Ruak (The Ancient Town of Wiang Chiang Miang)}

An arcuate (bow-shaped) moat-like trench is located at the south side of the village of Sop Ruak, in Chiang Rai Province (FIG. 2). The feature runs from the bank of the Mekong River westward $0.6 \mathrm{~km}$ to the 100 -m long pond that borders the hillside. The pond and rice field to the south are clearly located on an old side channel of the Mekong. They were likely in existence at a time when the area now occupied by Sop Ruak may have been an island. The western part of the trench has been leveled; only the eastern $0.4 \mathrm{~km}$ is preserved. The inner wall is $5 \mathrm{~m}$ high, the upper meter comprised of a mound, $1 \mathrm{~m}$ high (FIG. 10). 


\section{Chiang Saen Brick Wall and Earthen Moat}

The brick wall and earthen moat of Chiang Saen encloses an area of about $2 \mathrm{~km}^{2}$ (FIG. 2). Within the ancient city are at least 75 brick monuments, mostly Lan Na age stupa and temple foundations in various states of restoration (The $8^{\text {th }}$ Regional Office of Fine Arts 2006). This moat and wall system was clearly built for defense of the city. The walls were almost certainly maintained by the Burmese military until the time of their defeat in 1804 A.D.

The brick wall encircling Chiang Saen was partly excavated and reconstructed A.D. 2009-2013 (Sivakorn Karn Chang, Co., Ltd. 2013). Excavation revealed older earthen walls 3-m high beneath the brick walls. The apparent ages of 13 soil and brick samples from the excavations were determined by Dr. Krit Won-in at the Thermoluminescence Laboratory of Kasetsart University. One brick age A.D. $327 \pm 143$ and six soil chunk samples ranged in age from A.D. 327-776. Another brick age was A.D. 974 \pm 83 and two soil samples ranged from A.D. 710936. Three brick samples, presumably from the uppermost brickworks, ranged from A.D. 1330-1531. We presume the thermoluminescence analysis are on coarse-quartz-grain separates as described by Won-in et al. (2008). The report available to us (Sivakorn Karn Chang, Co., Ltd. 2013) does not give details on sample processing, consideration of adequate bleaching, or stratigraphy of sample locations. These ages are intriguing because they are the first dated physical evidence to corroborate chronicle legends of a pre-Lan Na city at Chiang Saen, and we await interpretation by Thai colleagues of their significance. An important pre-La Na city surely existed at this site.

The chronicles write that King Mangrai, the founder of the La Na Kingdom descended from a lineage of rulers beginning in A.D 639, and was born here in A.D 1238 (Wyatt and Wichienkeeo 1998: 9; Wyatt 2003: 34). The foundation of Chiang Saen as a walled fortress is credited to the reign of his grandson, Saen Phu, in A.D. 1329. Wyatt and Wichienkeeo (1998: 59) have translated from the chronicles: "He had a moat dug around the city on three sides - the moat on the eastern side being the Mekong River - and had walls built on all three sides; and Saen Phu then reigned in that city which has been called Chiang Saen to the present day". The chronicles write that Chiang Saen was built in A.D. 1327/28 and 1329), measuring 1500 fathoms by 700 fathoms [3000 by $1400 \mathrm{~m}$ ] with five gates (Wyatt and Wichienkeeo 1998) The moat may have been filled by water from the $2-\mathrm{km}^{2}$ drainage area of Huai Hom ("Huai" means stream in Thai language) via the old oxbow of the Mekong, Nong Bua, or from the much larger Huai Kiang ( $>20 \mathrm{~km}^{2}$ drainage area, shown on map of Wood et al. 2008: fig. 2). Dry season water from the Mekong or the nearby Kham River is 5-10 m lower than the moat. Therefore these streams seem unlikely sources of moat water. Access to water from these streams to fill the moat may have been a factor in the original engineering of the town.

There has clearly been erosion of the Mekong River bank at Chiang Saen, Chiang Saen Noi, and Sop Ruak, and across the river at "Souvannakhomkham" (Wood and Wood, 2009), but there is no evidence that a moat, entrenchment or wall ever existed on the Mekong River sides of these cities.

We surveyed the profile of a segment of the crumbled wall prior to its reconstruction in 2013. Relief from the bottom of the moat to the top of the wall is 8 meters. In a cross section, the vertical outer brick part of the wall appears to be 5-m high (FIG. 10). The moat was 10-m wide and 3-m deep below the wall. It is not known how the sloping walls of the moat were maintained. If water-filled, a vertical slope would not have been stable. The present slope of the inner and outer sides of the moat are $38^{\circ}$ and $40^{\circ}$, respectively (FIG. 10). The degraded slope of the crumbled brick wall is $41^{\circ}$. These slopes are similar to the other surveyed earthworks.

[FIG. 10]

\section{Other Earthworks not Surveyed}

Much of the rambling entrenchment on the west side of Mae Sai has been filled by development. We surveyed a remnant on the south side, but the result is questionable (TABLE 1). The earthworks at Thoen (Jumsai, 1970) were not examined, nor were the many sites mention by Ongsakul (2005) and Thiva Supajanya (unpublished). We have seen the Google Earth images of similar earthworks at Si Don Mun, Kok River Valley, and Fang (TABLE 1), but did not visit them. 


\section{Purpose of the Earthworks}

The entrenchments examined must have originally been constructed with near vertical walls. In this region of Thailand, the cohesive clayey soil mantle of hills can be hand- excavated with a hoe and shovel to depths exceeding 5 meters, down into the saprolite. Furthermore, walls more than $10 \mathrm{~m}$ high will stand at a steep angles $\left(>60^{\circ}\right)$ for many years - in part, because of cohesion of the red-clay soil, and also because of the case- hardening by iron oxides of the exposed surface of lateritic soil. For the sites where the material is clayey floodplain silt (described by Wood et al., 2008) excavation is easier; and recently cut river banks remain nearly vertical for several years. As the entrenchments have not been used in recent times, the walls have eroded to slope angles of $29^{\circ}$ to $47^{\circ}$.

These entrenchments may have had a log stockade to help them be a more effective defensive or containment structure. If for containment, presumably the stockade would have been built along the outside perimeter. If for defense against an invading army with elephants, the stockade would have been built at the top of the inside embankment. When the earthworks fell into disuse, these log structures, if they existed, would have rotted away, or have been carted off for building other structures. We did not excavate but it is possible that excavation might find post-hole evidence of stockades

Although little is known of life in the region prior to the $13^{\text {th }}$ century, one need only read a few pages of the Chiang Mai Chronicle (Wyatt and Wichienkeeo, 1998) to learn that towns of sizeable population and wealth were often attacked by bandits, neighboring rulers and the Chinese Ho invaders, prior to and during Lan Na time. Clearly, many of the earthworks described in this paper were not moats, as they were constructed across hills. Therefore, we hypothesize they were used for containment of elephants or perhaps had a dual purpose of also providing a semidefensible area to which villagers could flee when attacks were anticipated.

The manual effort to construct one of these circular trenches was considerable. The circumferences we surveyed were typically 1.2 to $2 \mathrm{~km}$ in length; and the cross- sectional areas were roughly $50-60 \mathrm{~m}^{2}$. Thus, the excavation of the $1.2-\mathrm{km}$ length double trench at Wat Phraison Kiri involved removing $72,000 \mathrm{~m}^{3}$ with hand tools. If we assume two manual laborers can excavate and remove 3 to $8 \mathrm{~m}^{3}$ per day (Stiedl, 1968), a feat of this nature would require 18,000 to 48,000 person days. It would have taken 200 workers several months to complete the earthwork. This seems an attainable effort for an army to trap/contain elephants or for a defensive structure. Likely some or all of the work was done by corvèe or captive labor.

Warfare in Asia involved elephants until the late $19^{\text {th }}$ Century (Nossov, 2008, p. 32). Entrenchments, stockades, and moats would have been constructed to deter attacks with elephants. Certainly a 3-m high vertical earthen wall would impede an elephant, and could only be surmounted by foot soldiers with a ladder. Sukamar (2003: 365) indicates a trench $2 \mathrm{~m}$ deep, $2 \mathrm{~m}$ across the top, and $1.5 \mathrm{~m}$ across the bottom would be sufficient to contain or prevent elephants from crossing into agricultural areas. If used for defense, we recognize that some double-trench earthworks are designed poorly. For example, soldiers standing at the top of the inner trenches of double trench systems had limited view of the outer trench. Thus, they could not fire arrows [or gunfire at later times] at attackers who sought refuge in the outer trench.

The most puzzling entrenchments are those that do not encircle areas with potsherds and brick debris of pre-existing villages. It is quite possible that these were constructed to capture and contain elephants, regardless of their potential for military defense. Nanjappa (2011) writes that the capturing of elephants in pens or stockades is a widely known method known as Khedda. This word is derived from the Hindi word khedna, which in turn is derived from the Sanskrit khet, which means to drive. Elephants were literally driven into pens or stockades. Najappa (2011) further writes:

The original method as practiced in Northern India by the people loosely termed 'Aryan' was a simple large space enclosed by a circular trench. The trench was usually thirty feet wide and twenty four feet deep. The excavated soil was thrown up into a steep bank on the outside. The only entrance was a bridge covered with a deep layer of earth, turf and leaves strong enough to take the weight of elephants. Female decoy elephants were kept in the enclosure. Men kept a watch from hiding places in the bank of earth and once a wild herd entered the enclosure they would demolish the bridge thus effectively trapping the herd. The trapped herd would be kept without food and water and after a while the bridge would be rebuilt and domesticated elephants introduced to 
subdue the wild herd. This method of capturing elephants evolved over time. For example, walls were added; trenches may have been added for reinforcment; bridges were replaced by gates; and wild elephants were driven in instead of being lured by decoys.

Interpretation of some of the earthworks as "elephant corrals" explains their association with nearby villages, and the absence of temple ruins or pottery sherds within the enclosure.

\section{Age of the Earthwork Excavations}

From historical accounts, the Lan Na time ( $\sim 55$ to 720 years ago) is the most likely time when these earthworks were built. Earlier towns surely existed in northern Thailand, but no sites have been confirmed other than Dvaravati towns near Lamphun. Furthermore, favorable town sites would have been rebuilt during Lan Na time, and many earlier earthworks modified. The earthworks were likely maintained during times of hostilities; and we cannot be certain that they were left to decay during Burmese occupation. Because hostilities generally stopped in A.D. 1804, there was no need to maintain the earthworks, unless they were used for other purposes, such as elephant containment.

To test our hypothesis that the earthworks were abandoned 400-500 years ago, we employed Equation 1 and the methods outlined in the appendix to generate several curves for various values of $k \tau$ and $\theta 0$. The curve of this equation that best fits most of the data points is the heavy solid line of FIG. 11 for which $\mathrm{k} \tau=0.79 \mathrm{~m}^{2} ; \theta 0=50^{\circ}$. We do not perform a rigorous error analysis of curve fitting, but inspection of FIG. 11 shows that curves for $\theta 0=50^{\circ}$, and $\mathrm{k} \tau$ values between 0.5 and $1.0 \mathrm{~m}^{2}$ contain most of the data, and error on $\mathrm{k} \tau$ is about $\pm 0.25 \mathrm{~m}^{2}$. If we assume most of the entrenchments were maintained up to the time of Burmese occupation 455 years ago, and that the initial collapse of the walls occurred over 55 years, our estimated value for $\mathrm{k}$ is $0.0020 \mathrm{~m}^{2} \mathrm{y}^{-1}$ (calculated as $\mathrm{k}=0.79 \mathrm{~m}^{2}$ / 400 years, as discussed in the Appendix). From discussion above of the possible error in $k \tau$ values, the associated error in $\mathrm{k}$ is $\pm 0.0006 \mathrm{~m}^{2} \mathrm{y}^{-1}$. With this calibration of the $\mathrm{k}$ value we produce a different curve (FIG. 11) that passes through the points for Souvannakhomkham $\left(\mathrm{k} \tau=1.99 \mathrm{~m}^{2}, \theta 0=50^{\circ}\right)$, and we get a value of 995 years for $\tau$. Given the uncertainty in the estimate of $k$ discussed above, the age likely falls in the period A.D. 600-1250, which is realistic for the earlier, abandoned, defensive entrenchment built across the Mekong River from the city of Chiang Saen.

[FIG. 11]

\section{Conclusions}

The several earthworks we survey in northern Thailand and Laos are preserved with remarkably steep slopes (29$47^{\circ}$ ). Similarity of slopes indicate that they were likely constructed in a common time period; and they likely were maintained during the Lan $\mathrm{Na}$ time (A.D. 1296-1558). Only the slopes of the 3-m high entrenchment around Souvannakhomkham have distinctly lower sloping sides, $29-32^{\circ}$, suggesting an age of A.D. 600-1250. The complicated and intersecting ovoid map patterns of entrenchments are not easily explained, except that some sections along the trenches could have captured and conveyed water, but could not have held water for a moat. If for defense during a village siege, or if for an elephant corral, the enclosure likely had a water supply. No inner reservoirs are observed, but some have perennial springs (Wat Phraisan Kuri) or are partly bounded by a low wet area or wet rice fields (e.g., sites at Phrao, Ban Huai Wiang Wai, Ban Nong Pung; FIG. 1, 2).

The purpose of the double trench is uncertain. A $>2$-m trench is deep enough to be a barrier to contain or prevent the advance of elephants (Sukamar, 2003:365). The inner small encirclement approximately $2 \mathrm{~m}$ deep at Wat Phraison Kiri, may have been for culling elephants. Only at one of these double and single trench systems did we find bricks or pottery shards indicating an abandoned village. Clearly the rectangular earthwork of Souvannakhomkham, and the half-circle at Chiang Saen Noi, encircle a previously inhabited area. The entrenchments combined with the steep river banks, must have been built for defense against invaders and perhaps wild animals (e.g., tigers, rhinoceros, elephants). Similarly the rambling trench outline of Mae Sai (now mostly filled and leveled for modern development) was likely for defense. 
We hope our examination of slope-degradation ages may be useful for archaeologists and geologists as other earthworks and scarps are examined in Southeast Asia, and where the slope geometry suggests significant age differences. This study establishes the location of these features in hope that they will be preserved as sites of interest to tourism and archaeological heritage. These ancient sites will be lost forever if they are graded for agricultural or other economic developments.

\section{Appendix}

\section{Diffusion Model for Slope Degradation}

In this work we make the assumption that these earthworks were originally excavated with vertical or near-vertical walls, assuming their purpose was for defense or elephant containment. We draw from the body of literature that has been published on the degradation of steep scarps formed by earthquakes in our dating of the age of the scarp formation (Nash 1980; Colman and Watson 1983). This application has been extended to investigations of stream and wave cut banks (Hanks et al. 1984; Pierce and Colman 1986) and to archaeological earthworks and stone walls (O'neal et al. 2005; Pelletier 2008, p. 45).

An unmaintained, steep-walled earthwork will crumble and erode to a shallow slope over time. The process of slope degradation first involves rain-splash erosion, raveling, slumping and crumbling of the material of the wall accompanied by falling and sedimentation of these materials at the base of the wall. Once the "free face" has been eliminated, a smooth arcuate-upward slope evolves. Slope degradation can then be modeled as diffusion process (FIG. 12). The time for this initial "mass-wasting" is uncertain, but estimates are 10 to 1000 years (Kogan and Bendick 2011). Important to the diffusion equation modeling of age is the time ( $\tau 0$; years) required for the removal of the free face, and the initial mid-slope angle ( $\theta 0$; degrees) at that time, which is commonly assumed to be the "angle of repose".

A key assumption for modeling this process as a diffusive process is that the volume rate of downslope soil transport per unit distance laterally along the slope $\left(\mathrm{R} ; \mathrm{m}^{3} \mathrm{~m}^{-1} \mathrm{y}^{-1}\right)$ is proportional to the local slope, $\frac{\partial z}{\partial x}$

(FIGURE. 12):

$$
R=k \times \frac{\partial z}{\partial x}
$$

where the $\mathrm{k}$ is the diffusion coefficient $\left(\mathrm{m}^{3} \mathrm{~m}^{-1} \mathrm{y}^{-1}\right)$, which depends upon the erodability of the soil, the frequency and intensity of slope erosion and slope wash events, and soil creep processes.

A second requirement in modeling this diffusion process is consideration of the continuity equation, which requires that the rate of change in height ( $\mathrm{z}$; meters) at any given point is equal to the incremental change in the rate of downslope transport, over an incremental downslope distance $\mathrm{x}$ (meters):

$$
\frac{\partial z}{\partial t}=\frac{\partial R}{\partial x}
$$

Depending upon initial conditions, solutions involving these equations can involve complicated mathematics (Hanks and Andrews, 1989). The following simple solution, which exists for an initially vertical face of height $\mathrm{h}$ (meters), imposed on a slope of angle $\alpha$ (degrees) that evolves over time ( $\tau$, years), can be used to illustrate the evolution of a slope by linear diffusive processes (FIG. 12): 
$y(x, \tau)-{ }_{2}^{h} \operatorname{erf}\left(\begin{array}{c}x \\ (k \tau)^{1 / 2}\end{array}\right)+x \tan \propto$

where $\mathrm{x}$, and $\mathrm{k}$ are as defined above; and erf is the error function, or the Gauss error function, a non-elementary function of sigmoid shape that occurs in probability, statistics and partial differential equations.

However, it is known that the early evolution of the slope is more complicated than the process represented by Equation A3. Most diffusion models therefore start with an assumed slope angle $\theta 0$ (again, near the angle of repose) that has developed by collapse of the free face over some elapsed time, $\tau 0$ (years). Although Hanks and Andrews (1989) give a solution to the condition of slope evolution with a starting slope angle $\theta 0$, the equation does not lend itself to simple calculations. If one considers only the evolution of the mid-slope angle $(\theta \mathrm{m})$ over time (See the midslope point where $\mathrm{x}=0$ on FIG. A1), the equation for time reduces to (Colman and Watson, 1983):

$\tau=\left(\mathrm{h}^{2} / 4 \pi \mathrm{k}\right)(1 /(\tan \theta \mathrm{m}-\tan \alpha))$

where $\mathrm{x}, \tau, \mathrm{h}, \mathrm{k}, \alpha, \theta \mathrm{m}$, and $\theta 0$ are all defined as above and shown in FIG. 12. In the equation, total time is recast into two time periods: (1) the period (represented by $\tau 0$ ) when the free face of the scarp collapses to an angle of repose; and (2) the time interval (represented by $\tau$ ) over which $\theta \mathrm{m}$ diminishes via diffusive processes. Solving Equation A4 algebraically, and setting $\alpha=0$ (nearly horizontal "far-field slope") gives the following equation for $\theta \mathrm{m}$ :

$\left.\theta \mathrm{m}=\arctan \left[\left(4 \pi \mathrm{k} \tau / \mathrm{h}^{2}\right)-\cot ^{2} \theta 0\right)\right]^{-1 / 2}$

Anderson and Bucknam (1979) showed that the easiest measurement is that of the mid- slope angle $(\theta \mathrm{m})$ and the height (h) of the scarp. If one plots these measurements for a group of degraded slopes on a $\theta \mathrm{m} v \mathrm{vs}$ graph, scarps having the same age $\tau$ and the same slope diffusion constant $\mathrm{k}$ should follow a curve of equation (A5). Several curves for selected values of $\mathrm{k} \tau$ and $\theta 0$ are shown in FIG. 11. The data points (h, $\theta \mathrm{m})$ generally follow the arcuate shape of these curves. High values that lie above these curves may be slopes steepened by recent excavation for road access to cultivated areas.

It is usually assumed that the diffusion constant $\mathrm{k}$ is the same for similar materials in a region. If groups of values follow different curves on the $\theta \mathrm{m}$-versus-h graph, they should be of different age. Pierce and Colman (1986) show that the linear diffusion equation and the associated constant $\mathrm{k}$ have inaccuracies, and that high scarps degrade faster than predicted. Again, the value of $\mathrm{k}$ is dependent on many processes that are not easily quantified. Nevertheless, the concept of diffusive processes diminishing the slope angle is a useful way to estimate age differences of degraded slopes.

For example, each curve in FIG. 11 has characteristic values of $\mathrm{k} \tau$, and $\theta 0$. A curve with $\mathrm{k} \tau=0.79 \mathrm{~m}^{2}$ and $\theta 0=50^{\circ}$ provides a good fit for most of the data. Points lying below this curve are in principal older (i.e., $\mathrm{k} \tau$ is greater), or the initial slope is less (i.e. $\theta 0$ is $<50^{\circ}$ ). In other words, points below this curve are slopes that are more degraded that the others (i.e. those that fit the curve).

\section{Application to the Earthworks in Thailand}

We have no data to estimate time, except that all but a few of the slopes measured in this study are smooth curves at an angle shallower than the angle of repose for loose material $\left(\sim 45^{\circ}\right)$. In local road cuts 5 -m high, debris typically accumulates halfway up the cut to an angle of $55^{\circ}$, just below marks of the excavator. Published values for failure angles of stiff and firm clay are 56 to $63^{\circ}$. We therefore believe our observed value of $55^{\circ}$ is a reasonable estimate of the angle of repose for these deep clay-rich cohesive soils in northern Thailand, rather than a value $\leq 45^{\circ}$ reported for cohesionless soils, such as those affected by manual tillage in Thailand and Vietnam (Ziegler and Sutherland, 2009; Ziegler et al. 2007).

A complication observed in recent northern Thailand road cuts, is that the free face commonly exhibits an iron-oxide encrustation that preserves excavator marks for many decades thus preserving the free face more so than in soils in temperate climates. However, this is a region of high monsoonal rainfall $\left(\sim 1500-1900 \mathrm{~mm} \mathrm{y}^{-1}\right)$, subtropical 
temperatures (mean annual temperature of $25.5^{\circ} \mathrm{C}$, and very warm afternoon temperatures of 31 to $36^{\circ} \mathrm{C}$ in the hot dry season extending from February-May, and dense vegetation. Therefore these cuts are frequently exposed to driving intense rain, extreme drying, as well as tree-throw and soil churning - so that the rates of slope evolution may not compare to the many studies done on gravelly soils of temperate and cold climates. Thus, the diffusion constant $\mathrm{k}$ is not well known over the various surficial materials and climates of the earth, including Thailand.

In order to appreciate the meaning of $\mathrm{k}$, consider the transfer of a volume of material (FIG. A1) from the upper slope (A), to the lower slope (B) over a period of time. Further, the volume of transfer is only a function of time. The average rate of transfer from the upper slope to the lower slope will have the units $\mathrm{m}^{3} \mathrm{y}^{-1}$. As we are casting this equation as a two-dimensional view, using $\mathrm{x}$ and $\mathrm{y}$ coordinates, we are actually considering a one-meter length along the slope in the $3^{\text {rd }}$ dimension, producing units $\mathrm{m}^{3} \mathrm{~m}^{-1} \mathrm{y}^{-1}$. A simple evaluation of $\mathrm{k}$ is the linear average of volume transport over time.

A two-dimensional profile visualizes how much material must have been transferred from the upper part of a vertical cut to the lower part to produce a profile that is observed today. For example in FIG. 5 (profile A), the 7-m-high bank has a midslope angle of $46^{\circ}$. The triangular volume of material removed from a vertical bank and transferred by erosion to the slope below (shown by dotted line) is $7.2 \mathrm{~m} \mathrm{~m}^{3} \mathrm{~m}^{-1} \mathrm{y}^{-1}$. If the vertical wall has been degrading for 400 years to the present slope, the average rate of transfer is $7.2 \mathrm{~m}^{3} \mathrm{~m}^{-1}$ over 400 years, which is equivalent to $0.018 \mathrm{~m}^{3}$ $\mathrm{m}^{-1} \mathrm{y}^{-1}$. If we consider only the volume that has built up over an early-formed $50^{\circ}$ slope $(\theta 0)$, the rate is $0.95 \mathrm{~m}^{3} \mathrm{~m}^{-1}$ over 400 years or $0.0024 \mathrm{~m}^{3} \mathrm{~m}^{-1} \mathrm{y}^{-1}$. While this value has the same units and is similar to $\mathrm{k}$ in the diffusion equation model, it does not take into account the height of the scarp, nor the idea that the transport rate is proportional to the slope (equation (1)). We use the best-fit curve for most points from the diffusion equation model (equation A5), to derive a value for $\mathrm{k} \tau=0.79 \mathrm{~m}^{2}$, and for 400 years, we derive a value for $\mathrm{k}=0.002 \mathrm{~m}^{3} \mathrm{~m}^{-1} \mathrm{y}^{-1}$ (FIG. 11).

Avouac (1993) provides diffusion-coefficient values derived from scarps for semi-arid temperate climates ranging from 0.0003 to $0.005 \mathrm{~m}^{3} \mathrm{~m}^{-1} \mathrm{y}^{-1}$ (reported as $\mathrm{m}^{2} /$ year). Thus, the value we obtain is within the known range for slope diffusion coefficients, but point out that the value of $\mathrm{k}$ we obtain is for cohesive clayey floodplain and lateritic soil in a sub-tropical environment.

Regardless of the uncertainty in estimating $\mathrm{k}$, one can characterize degraded slopes in terms of $\mathrm{k} \tau$ and an assumed value of $\theta 0$ simply to compare relative age difference. The lack of variability with respect the computed curves of FIG. 11 suggests little differences in age; and we believe most are $\sim 450$ years old, except for the older entrenchment at Souvannakhomkham, Laos.

\section{Acknowledgements}

We thank many people for discussions and help in locating and surveying the earthworks: John Roberts of Sop Ruak, Ian and Wassana Smith of Chiang Saen, Kapkeo Xayavouthy of Houay Xai, Laos, and Singapore students: Amber Lin Yew Chan, Tan Shumin, Serene Ng, Ng Chee Kian, Rebecca Neo, Wong Jiayi (Felicia). Kraisin Unchaijin and Saiklang Jindasu (Chiang Mai National Museum) provided helpful discussions and publications from the Fine Arts Department. We appreciate helpful comments from Steve Colman and 2 anonymous reviewers.

Spencer H. Wood (Ph.D. 1975, California Institute of Technology, Pasadena) is Emeritus Professor of Geosciences at Boise State University. He has conducted fieldwork in the western U.S, and Thailand with interests in geomorphology, sedimentology, geophysical exploration, volcanology, paleoseismicity, geothermal resources and watershed hydrology.

Layle R. Wood (B.A 1962, University of Oregon, Eugene). She has conducted field work in Thailand on geomorphology and archaeology.

Alan D. Ziegler (Ph.D., 2000, University of Hawaii, Honolulu) is Professor of Geography at the National University of Singapore. He conducts field work in SE Asia on environmental issues, catchment hydrology, and geomorphology. Current work compares environmental effects of traditional swidden agriculture with intensified and plantation cultivation on sloping lands of SE Asia., Other research concerns hydrological process related to infectious diseases and human health in developing countries. 


\section{References}

Avoac, J.-P., 1993. “Analysis of scarp profiles: evaluation of errors in morphologic dating,” Journal of Geophysical Research 98: 6,745-6,754.

Boyd, W.E, McGrath, R, and Higham, C.F.W., 1999a. "The Geoarchaeology of Iron Age"Moated" Sites of the Upper Mae Nam Mun Valley, N.E. Thailand. I: Palaeodrainage, Site-LandscapeRelationships and the Origins of the "Moats," Geoarchaeology 14: 675-716.

Boyd, W.E, McGrath, R, and Higham, C.F.W., 1999b. "The geoarchaeology of prehistoric ditched sites of the upper Mae Nam Mun Valley, NE Thailand, II: Stratigraphy and morphological sections of the encircling earthworks," Bulletin of the Indo-Pacific Prehistory Association, (Melaka Papers, Volume 2) 18: 169-179.

Bucknam, R.C. and Anderson, R.E., 1979. "Estimation of fault-scarp ages from a scarp- height-slope angle relationship," Geology, 7: 11-14.

Chaiseno, Boosaya, 1987. A study on archaeological evidence at the ancient town in Ampoe Chiang Saen, Changwat Chiang Rai. Unpublished M.A. thesis, Department of Archaeology, Silpakorn University, Bangkok.

Colman, S.M., and Watson, K., 1983. "Ages estimated from a diffusion equation model for scarp degradation," Science 221: 263-265.

Dega, M.F., 1999. "Circular settlements within eastern Cambodia," Bulletin of the Indo- Pacific Prehistory Association 18: 181-190.

Garnier, F., 1885. Further Travels in Laos and Yunnan, The Mekong Exploration Commission Report (1866-1869)Volume 2. Translated by W.E.J. Tips, and published in 1996, Bangkok: White Lotus Press, 291 p.

Glover, I., 2010. "The Dvaravati Gap - Linking prehistory and history in early Thailand,". Bulletin of the IndoPacific Prehistory Association 30: 79-86.

Hanks, T.C., and Andrews, D.J., 1989. "Effects of far-field slope on morphological dating of scarplike landforms," Journal of Geophysical Research, 94: 565-573.

Higham, C.F.W., 2002. Early Cultures of Mainland Southeast Asia.. Bangkok: River Books, 375 p.

Higham, C. and Thosarat, R., 2012. Early Thailand: From Prehistory to Sukhothai., Bangkok: River Books. 288 p.

Jumsai, Sumet., 1970. SEEN, Architectural Forms of Northern Siam and Old Siamese Fortifications: Bangkok: Fine Arts Commission of the Association of Siamese Architects, $200 \mathrm{p}$.

Kogan, L. and Bendick, R., 2011. "A Mass Failure Model for the Initial Degradation of Fault Scarps, with Application to the 1959 Scarps at Hebgen Lake, Montana," Bulletin of the Seismological Society of America 101: 68-78.

Leksukhum, S. 2005. "The evolution of memorial towers of Siamese temples," in F. McGill and P. Chirapravati, eds., The Kingdom of Siam: The Art of Central Thailand (1350-1800), The Asian Art Museum of San Francisco, pp. 61-79. Chicago: Art Media Resources.

le May, R., 1926. An Asian Arcady: Land and Peoples in Northern Siam. reprinted in 1999 by White Lotus Press, Bangkok. $268 \mathrm{p}$.

Lertrit, S., 2000. "Cultural resource management and archaeology at Chiang Saen, Northern Thailand," Journal of Southeast Asian Studies 31(1): 137-161.

Lorrillard, M., 2000. "Souvanna Khom Kham ou Chiang Saen rive gauche?,” Aséanie 5: 57-68.

Nash. D.B., 1980. "Morphologic dating of degraded normal fault scarps," Journal of Geology 88: 353-360

Nanjappa, V., 2011. A brief history of elephant capture and methods employed - Part 1, (http://gaur36.livejournal.com/119079.html)

Nossov, K., 2008. War Elephants. Oxford: Osprey Publishing Co. 48 p.

Notton, C., 1926. Analles du Siam. Chronique de Sinhanavati. Paris: Imprimeries Charles-Lavaunzell \& Cle, pp. 142-209.

O’Neal, M.A., O’Mansky, M.E., and MacGregor, J.A., 2005. "Modeling the natural degradation of earthworks," Geoarchaeology 20(7):739-748.

Ongsakul, S., 2005. History of Lanna. Chiang Mai: Silkworm Books, 328 p.

O'Reilly, D.J.W., 2001. "From the Bronze Age to the Iron Age in Thailand: Applying a heterarchical approach," Asian Perspectives 39: 1-19.

Parry, J.T., 1992. "The investigative role of Landsat-TM in the examination of Pre-and Proto-historic water management sites in northeast Thailand," Geocarta International 4: 5-24.

Pautreau, J.-P., Mornais, P., and Doy-Asa, T., 2003. BanWang Hai, excavations of an Iron-Age cemetery in northern Thailand. Silkworm Books, Chiang Mai. 248 p.

Penth, H.G., 1972. "Old Phrao," The Journal of the Siam Society 60: 1-4. 
Penth, H., 1994. The Jinakalamali Index, an Annotated Index to the Thailand Part of Ratanapanna's Chronicle Jinakalamali. Oxford: The Pali Text Society; and Chiang Mai, Silkworm Books. 358 p.

Penth, H., 2004. A Brief History of Lā Nā, Northern Thailand from Past to Present.

Chiang Mai: Silkworm Books, $166 \mathrm{p}$.

Pelletier, J.D., 2008. Quantitative Modeling of Earth Surface Processes. Cambridge: Cambridge University Press. $295 \mathrm{p}$.

Rattanavong, Houmphanh, 1999. "Souvannakhomkham: An ancient city of Laos".

Unpublished manuscript translated to English by Somsanouk Mixay, obtained by the authors from guides in Houay Xai, Laos, in 2006.

The $8^{\text {th }}$ Regional Office of Fine Arts. 2006. The historic city of Chiang Saen. Illustrated brochure published by the Thai Fine Arts Department, Chiang Mai.

Sivakorn Karn Chang Co., Ltd. 2013. Reconstruction of the Chiang Saen City wall (2009-2013). Report to the Department of Fine Arts, Bangkok. 220 p. (in Thai).

Shinawatra, Weeraphan, 2007. The Cultural Landscape Associated with the Old Town of Chiang Saen: the Interpretation and Conservation of a Forgotten Heritage, unpublished Ph.D. thesis. Faculty of Architecture, Silpakorn University, Bangkok.

(http://www.thapra.lib.su.ac.th/objects/thesis/fulltext/thapra/Weeraphan_Shinawatra Doctor/Chapter2.pdf).

Stiedl, D., 1968. Productivity norms for labour-based construction. International Labour Organisation, Advisory support, information services and Training, Nairobi, Kenya, $48 \mathrm{p}$. (http://www.ilo.org/public/english/employment/recon/eiip/download/prod_norms.pdf).

Sukumar, R., 2003. The Living Elephants; Evolutionary Ecology, Behavior, and Conservation. Oxford: Oxford University Press, $453 \mathrm{p}$.

Supajanya, Thiva, and Vallibhotama, Srisakra, 1972. "The need for an inventory of ancient sites for anthropological research in northeastern Thailand," Tonan Ajia Kenkyu (The Southeast Asian Studies) 10(2): 284-297.

Supajanya, Thiva, and Vanasin, Pongrsi. 1986. "The inventory of ancient settlements in Thailand on aerial photographs," Journal of the National Research Council, Thailand 18 (2):1-38 (in Thai).

Unchaijin, K., 2012. History of built settlements in Lan Na. Department of Fine Arts, Bangkok. 190 p. (in Thai).

Won-in, K., Wattanadul, P, Dararutana, P., Pongkrapan, S., Takashima, I., Ruangrunsri, N., Singharajwarapan, F.S., Supajanya, T., and Vichapan, K., 2008. "Preliminary study of the age of the Lanna Period by Thermoluminescence dating: A case study from the Wiang Kaen ancient site, Chiang Rai, Northern Thailand," in Kostov, R.I., Gavdarska, B., and Gurova, M., eds., Geoarchaeology and Archaeomineralogy, Proceedings of the International Conference, Sofia. p. 130-133.

Wood, S.H., Ziegler, A.D., and Bundarnsin, T., 2008. "Floodplain sedimentation, channel changes and riverbank stratigraphy of the Mekong River area, Chiang Saen, Northern Thailand," Geomorphology 101:510-523.

Wood, S.H., and Wood, L.E., 2009. "Mekong riverbank erosion of the $14^{\text {th }}$ Century cities of Chiang Saen Noi, Thailand and Souvannakhomkhanm, Laos, PDR," Geological Society of America Abstracts with Programs 41(7): 576.

Wyatt, D.K., and Wichienkeeo, A., 1998. The Chiang Mai chronicle, $2^{\text {nd }}$ edition. Chiang Mai: Silkworm Books, 234 p.

Ziegler, A.D., and Sutherland, R.A. 2009. "Modeling soil flux by manual tillage as a non-linear slope-dependent process," Soil Science Society of American Journal 73 (3): 1012-1019.

Ziegler, A.D., Giambelluca, T.W., Sutherland, R.A., Nullet, M.A., and Tran Duc Vien. 2007. "Soil translocation by weeding on swidden fields in northern Vietnam,”. Soil and Tillage Research 96: 219-233. 


\section{Table Caption}

Table 1: List of earthwork sites, Northern Thailand

\section{Figure Captions}

FIG. 1 Map of Thailand showing locations of rivers and cities discussed in this paper.

FIG. 2 Map showing locations of ruins and earthworks indicative of ancient settlement in the vicinity of Chiang Saen. Solid dots are locations of brick ruins of Lan $\mathrm{Na}$ era temples surveyed by students supervised by Narumon Ruangrunsri, Director of the Art and Cultural Center, Chiang Rai Rajabhat University in 2008. Solid circles in Laos are brick and stucco Buddhist monument ruins surveyed by Wood and Wood (2009: slide No. 10). Open circles are of Lan Na towns shown by Shinawatra (2007:. 200) believed to be derived from an unpublished work by Thiva Supanjanya of Chulalongkorn University, entitled "Analysis of old town and settlements around the basins of the Ruak, Kum, and Mae Chaen Rivers. Names of modern villages are posted near known earthworks discussed in this report. Shaded areas are lowlands mostly in rice paddy or orchard cultivation. Brick wall and moat surrounding Chiang Saen shown by heavy black line. Earthworks at Sop Ruak, Chiang Saen Noi, and Souvannakhomkham shown by a thin gray line.

FIG. 3 Map and Google Earth image of earthwork trench system at Ban Nong Pung, $11.2 \mathrm{~km}$ east of Mae Chan. Showing locations of profiles A and B. Solid line is trace of the trench, dotted line is trace of related earthworks not yet surveyed or profiled. Note that the trench crosses hill with relief of $\sim 25-\mathrm{m}$ just north of Wat Ban Nong Pung. Topographic contour interval is $20 \mathrm{~m}$, elevations labeled brown, with UTM 1-km grid coordinates (India-Thailand Datum).

FIG. 4 (a) and (b) are photos of walls of earthwork at Ban Nong Pung (FIG. 5). (c) walls of earthworks at Phrao, (d) photo looking south showing wall between the double trench at Phrao. Arrows point to people standing in the trenches. Foreground had been slightly graded for a mango orchard. Profile A (FIG. 5) is in the undisturbed area of trees in the distance (Photos by Tan Shumin and Amber Lin Yew Chan). (e) photo of the NE part of the earthworks near Wat Phraisan Kiri, showing the curved double trench system. Photo taken looking north from a point $200 \mathrm{~m}$ southeast of Profile B (FIG. 7).

FIG. 5 Map, Google Earth image, and profiles of the earthwork trench system $3 \mathrm{~km}$ east of Phrao (see FIG. 1 and Table 1 for location of Phrao). Locations of profiles A and B shown on map. Dashed line on profiles is the assumed shape of the original vertical-wall construction. Mid-slope angles are labeled. UTM 1-km grid coordinates (IndiaThailand Datum).

FIG. 6 Map and Google Earth image of earthwork trench system at Ban Huai Wiang Wai, 2.2 km east of Mae Chan. Location of profile shown on map. Dashed lines are the assumed configuration of the original trench and wall. with UTM 1-km grid coordinates (India-Thailand Datum).

FIG. 7 Map and Google Earth image of the double-trench earthwork near Wat Phraison Kiri, showing profiles across the earthworks, and its position on a 50-m high hill.

Topographic map with 20-m contours, with UTM 1-km grid coordinates (India-Thailand Datum).

FIG. 8 Map of area east of Chiang Saen showing location of brick temple ruins (A), location of profiles at Souvannakhomkham (A) and at Chiang Saen Noi (B and C). UTM 1-km grid lines (WGS-84 datum).

FIG. 9 (a) View looking west and uphill of the trench earthwork at Souvannakhomkham and location of profile A in FIG. 8. Person at left (south side) for scale. Bottom of trench is $10-\mathrm{m}$ wide, and trench is $3-\mathrm{m} \mathrm{deep}$. The trench system runs up the 40-m high hill in the distance and could not have held water. (b) ruins of a bell-shaped stupa at location R (FIG. 8) (c) ruins of a redented style (stupa-form terminology from Leksukam, 2005) stupa at location P on FIG. 8. (d) photo showing the earthen-walled moat and the partially reconstructed brick wall of the city of Chiang Saen. Degraded slopes down to the left are similar to those of most other earthworks in the region. 
This is an author-produced, peer-reviewed version of this article. The final, definitive version of this document can be found online at Journal of Field Archaeology, published by Maney Publishing. Copyright restrictions may apply. doi: 10.1080/00934690.2015.1103645

FIG. 10 (A) Profile of the brick city wall and earthen moat of Chiang Saen, just west of the Yang Thoen Gate (FIG. 2). The intact original brick discovered during excavation of the wall by the Fine Arts Department and posted on an information plaque at the site. Much of the inner wall (south side) has been reconstructed, but the outer wall and moat appear to have collapsed to slopes similar to earthworks elsewhere in the region. (B) Profile of the intact remnants of the earthwork on the south side of Sop Ruak (located on FIG. 2).

FIG. 11 Plot of earthen wall height (h) vs. maximum slope angle $\theta \mathrm{m}$. Various curves use different values of $\theta 0$ and $\mathrm{k} \tau$, with a best fit of the data for $\theta 0=50^{\circ}$, and $\mathrm{k} \tau=0.796$, according to equation (A5).

FIG. 12 Diagram showing parameters used in a model for slope degradation over time. 


\section{Table 1 Location and dimensions of earthwork sites in Northern Thailand}

\begin{tabular}{|c|c|c|c|c|c|c|c|}
\hline Site name & Latitude & Longitude & Area $\left(\mathrm{km}^{2}\right)$ & $\begin{array}{l}\text { No. of } \\
\text { con- } \\
\text { centric } \\
\text { trench- } \\
\text { es }\end{array}$ & $\begin{array}{l}\text { Wall } \\
\text { height } \\
(\mathrm{m}) \dagger\end{array}$ & $\begin{array}{l}\text { Trench } \\
\text { depth } \\
\text { (m)‡ }\end{array}$ & $\begin{array}{l}\text { Maximum } \\
\text { slope }\end{array}$ \\
\hline $\begin{array}{l}\text { Ban Nong Pung } \\
\text { (11 km NE of } \\
\text { Mae Chan) }\end{array}$ & $20^{\circ} 12^{\prime} 02.12^{\prime \prime} \mathrm{N}$ & $99^{\circ} 56^{\prime} 36.59^{\prime \prime} \mathrm{E}$ & 0.31 & 1 & 4.5 & 3.5 & $47^{\circ}$ \\
\hline $\begin{array}{l}\text { Wat Phrao Chao } \\
\text { Lan Thong ( } 3.4 \\
\text { km W of Phrao) }\end{array}$ & $19^{\circ} 21^{\prime} 59.21^{\prime \prime N}$ & $99^{\circ} 10^{\prime} 08.65 " \mathrm{E}$ & $\begin{array}{l}\text { (N) } 0.13 \\
\text { (S) } 0.16\end{array}$ & 2 & 7 & 5 & $43^{\circ}$ \\
\hline $\begin{array}{l}\text { Ban Huai Wiang } \\
\text { Wai ( } 2 \mathrm{~km} \text { E of } \\
\text { Mae Chan) }\end{array}$ & $20^{\circ} 09^{\prime} 21.12 \mathrm{~N}$ & $99^{\circ} 52^{\prime} 46.84^{\prime \prime} \mathrm{E}$ & $\begin{array}{l}\text { (N) } 0.33 \\
\text { (M) } 0.22 \\
\text { (S) } 0.38\end{array}$ & 1 & 7.5 & 4 & $43^{\circ}$ \\
\hline $\begin{array}{l}\text { Wat Phraison Kiri } \\
\text { (12 km E of Mae } \\
\text { Chan) }\end{array}$ & $20^{\circ} 09^{\prime} 19.87^{\prime \prime} \mathrm{N}$ & $99^{\circ} 57^{\prime} 56.80^{\prime \prime} \mathrm{E}$ & 0.41 & 2 & 8 & 5 & $42^{\circ}$ \\
\hline Chiang Saen Noi & $20^{\circ} 14^{\prime} 31.15^{\prime \prime N}$ & $100^{\circ} 06^{\prime} 55.74^{\prime \prime} \mathrm{E}$ & 0.68 & 1 & 5 & 4 & $44^{\circ}$ \\
\hline $\begin{array}{l}\text { Chiang Saen city } \\
\text { brick wall and } \\
\text { earthen moat }\end{array}$ & $20^{\circ} 17^{\prime} 04.22^{\prime \prime} \mathrm{N}$ & $100^{\circ} 05^{\prime} 03.45^{\prime \prime} \mathrm{E}$ & 2.42 & 1 & 8.5 & 4 & $43^{\circ}$ \\
\hline $\begin{array}{l}\text { Souvanna Khom } \\
\text { Kham, Laos }\end{array}$ & $20^{\circ} 15^{\prime} 34.50^{\prime \prime} \mathrm{N}$ & $100^{\circ} 07^{\prime} 13.38^{\prime \prime} \mathrm{E}$ & $\sim 1.00$ & 1 & 3.5 & 3 & $32^{\circ}$ \\
\hline Sop Ruak & $20^{\circ} 20^{\prime} 30.79^{\prime \prime} \mathrm{N}$ & $100^{\circ} 06^{\prime} 55.74^{\prime \prime} \mathrm{E}$ & 0.42 & 1 & 5 & 1.8 & $41^{\circ}$ \\
\hline Mae Sai & $20^{\circ} 25^{\prime} 17.04^{\prime \prime} \mathrm{N}$ & $99^{\circ} 52^{\prime} 53.08^{\prime \prime} \mathrm{E}$ & 2.37 & 1 & 6 & 6 & $37^{\circ}(?)$ \\
\hline Thoen* & $17^{\circ} 37^{\prime} 46.29^{\prime \prime} \mathrm{N}$ & $99^{\circ} 13^{\prime} 14.01 " \mathrm{E}$ & $0.10(?)$ & $2(?)$ & * & * & * \\
\hline $\begin{array}{l}\text { Kok River valley, } \\
\text { on route } 2111,10 \\
\text { km W of Huai } \\
\text { Khian (Highway } \\
1)^{\star}\end{array}$ & $20^{\circ} 05^{\prime} 59.14 " \mathrm{~N}$ & $99^{\circ} 58^{\prime} 10.23^{\prime \prime E}$ & $\begin{array}{l}\text { (N) } 0.006 \\
\text { (S) } 0.005\end{array}$ & 1 & * & * & * \\
\hline Fang* & $19^{\circ} 13^{\prime} 52.92 " \mathrm{~N}$ & $99^{\circ} 13^{\prime} 16.27^{\prime \prime E}$ & 0.20 & 1 & * & * & * \\
\hline $\begin{array}{l}\text { Si Don Mun, } 6.5 \\
\mathrm{~km} \text { W of Sop }\end{array}$ & & & & & & & \\
\hline $\begin{array}{l}\text { Ruak* }^{*} \\
\text { * site observed on } \\
\text { † wall height meas } \\
\text { † trench depth me }\end{array}$ & $\begin{array}{l}\text { ogle Earth but } n \\
\text { d from bottom o } \\
\text { red as depth bel }\end{array}$ & $\begin{array}{l}10001^{\prime} 04.29 " E \\
\text { jisited or surveyed } \\
\text { ench to top of inne } \\
\text { the original groun }\end{array}$ & sall & 2 & * & * & * \\
\hline
\end{tabular}




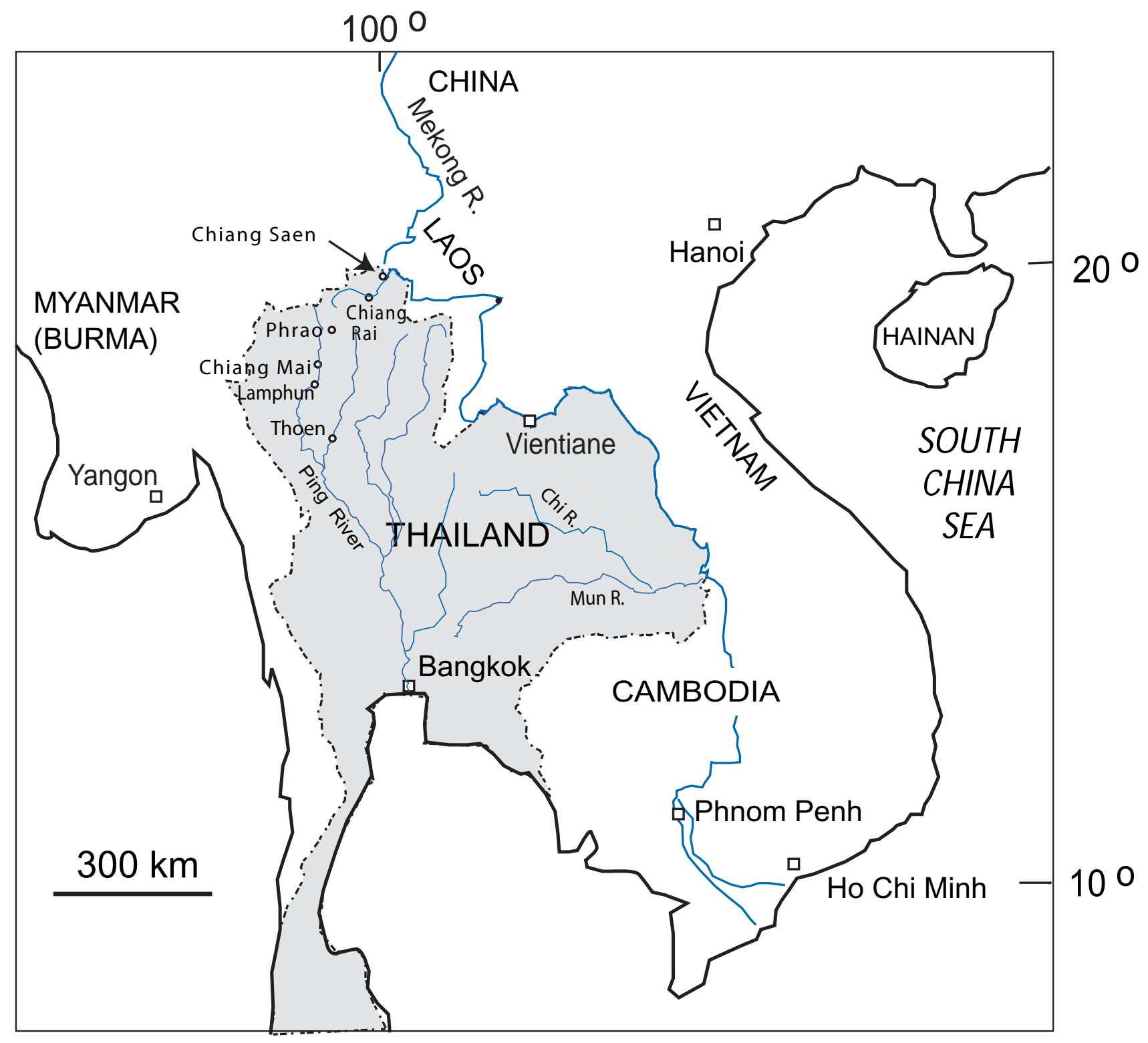




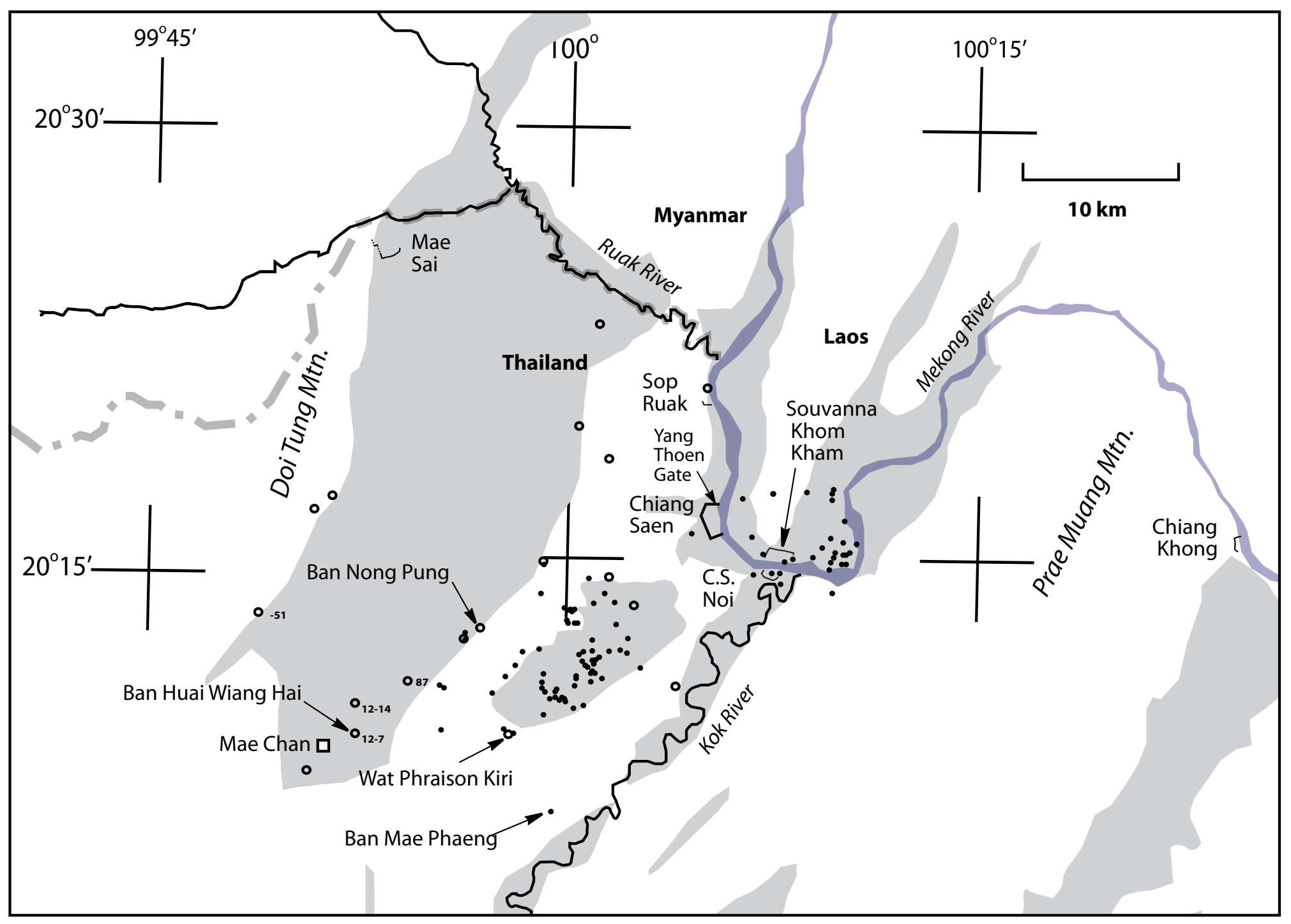

FIGURE 2 
This is an author-produced, peer-reviewed version of this article. The final, definitive version of this document can be found online at Journal of Field Archaeology, published by Maney Publishing. Copyright restrictions may apply. doi: 10.1080/00934690.2015.1103645
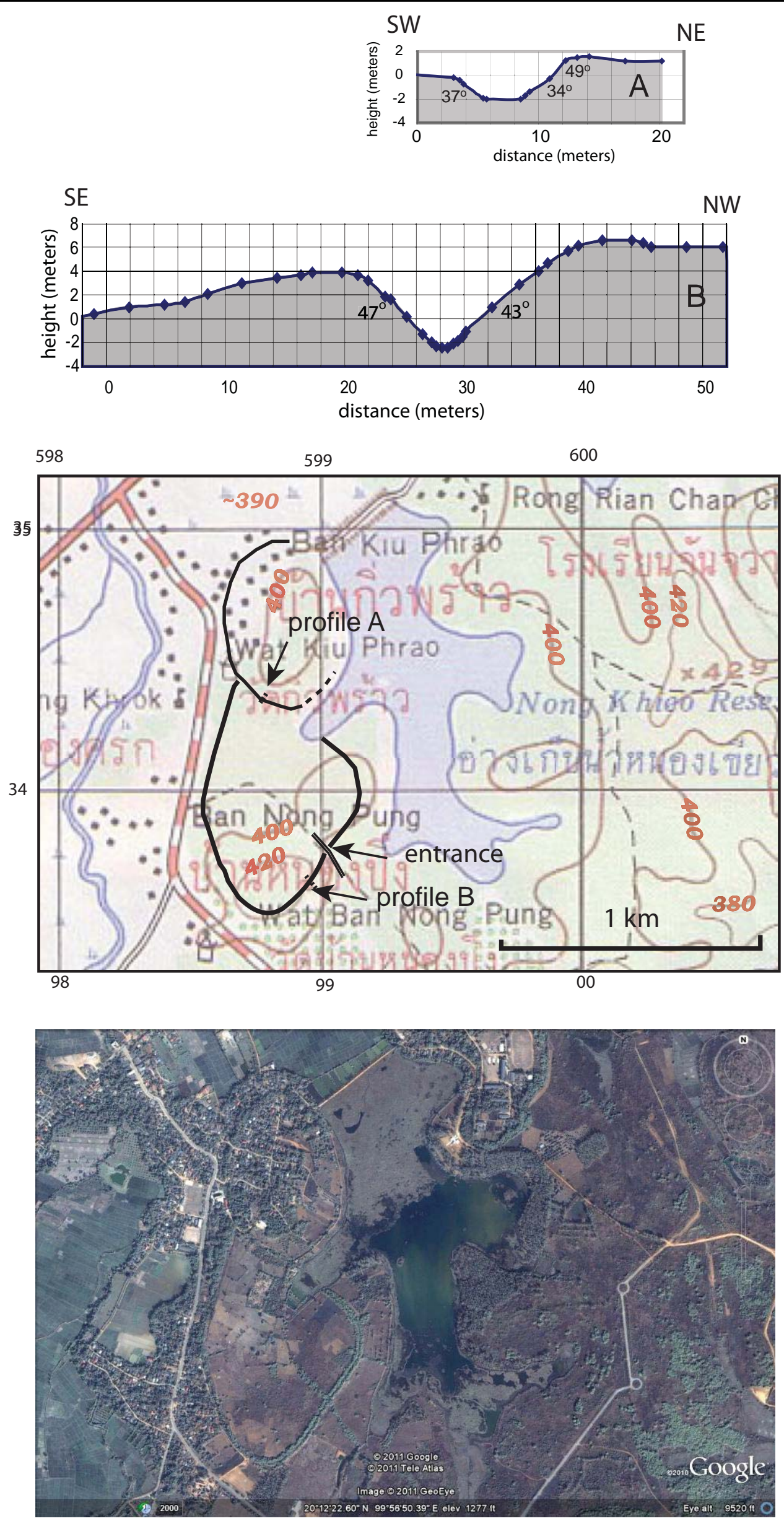
This is an author-produced, peer-reviewed version of this article. The final, definitive version of this document can be found online at Journal of Field Archaeology, published by Maney Publishing. Copyright restrictions may apply. doi: 10.1080/00934690.2015.1103645
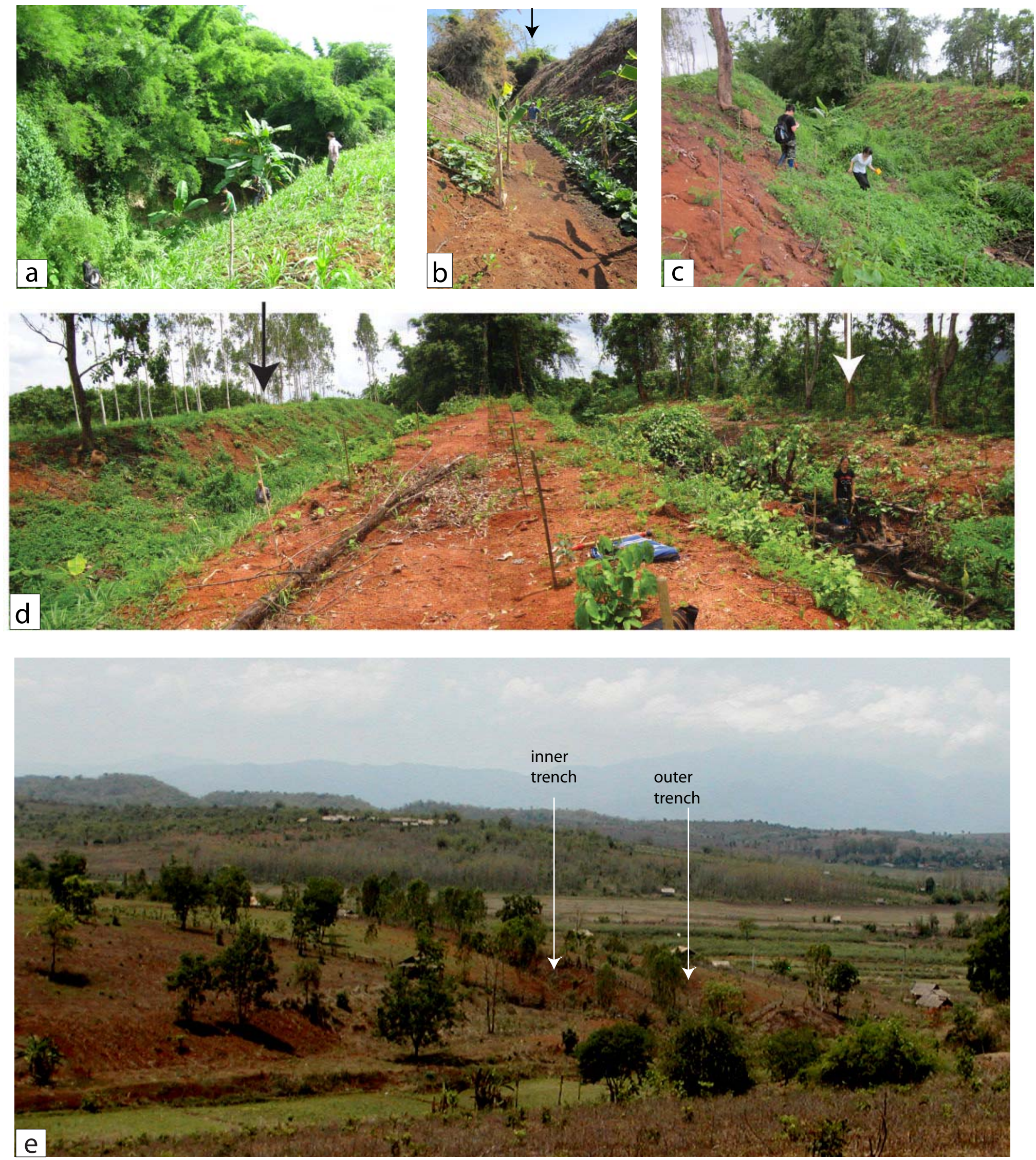

FIGURE 4 
This is an author-produced, peer-reviewed version of this article. The final, definitive version of this document can be found online at Journal of Field Archaeology, published by Maney Publishing. Copyright restrictions may apply. doi: 10.1080/00934690.2015.1103645
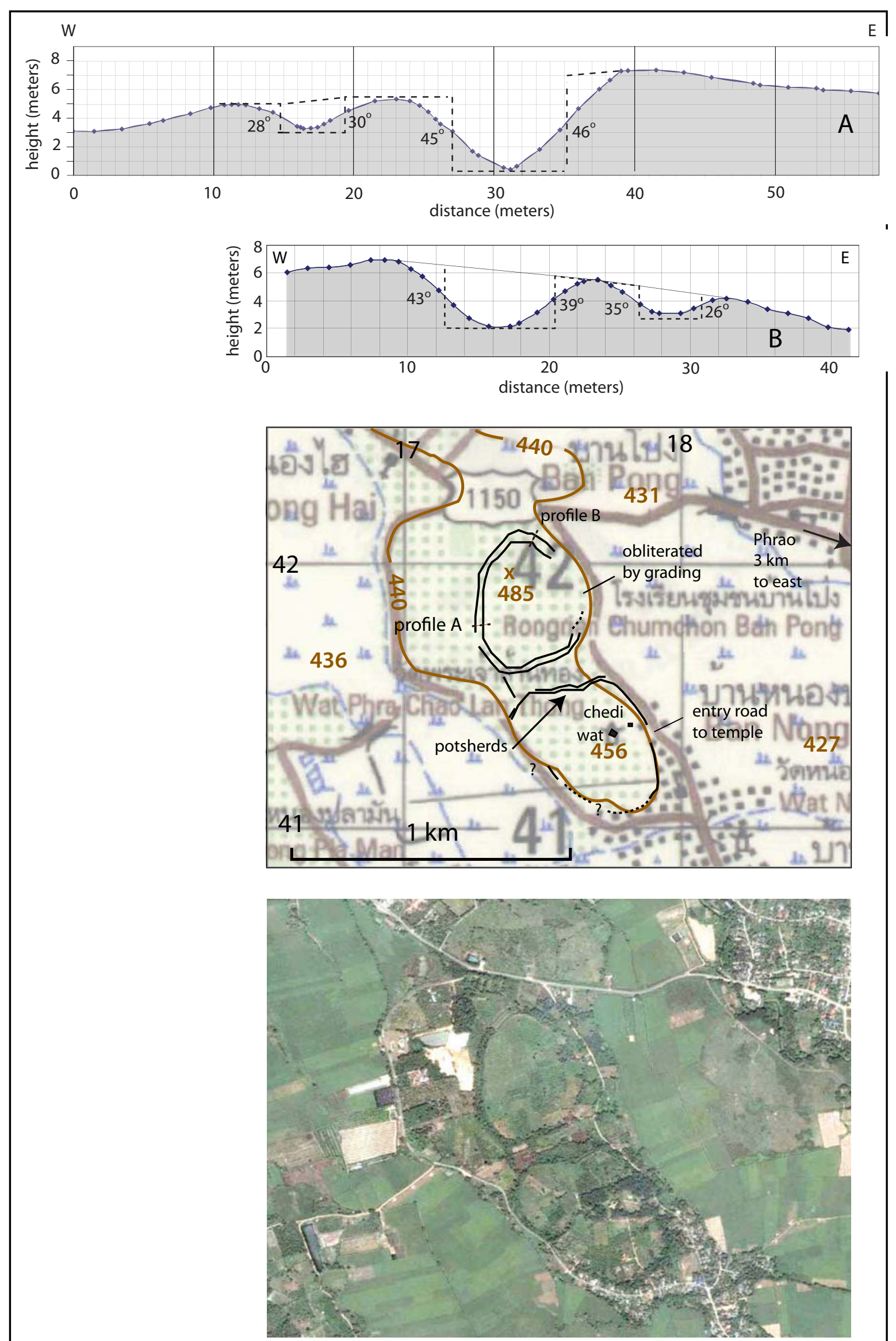
This is an author-produced, peer-reviewed version of this article. The final, definitive version of this document can be found online at Journal of Field Archaeology, published by Maney Publishing. Copyright restrictions may apply. doi: 10.1080/00934690.2015.1103645

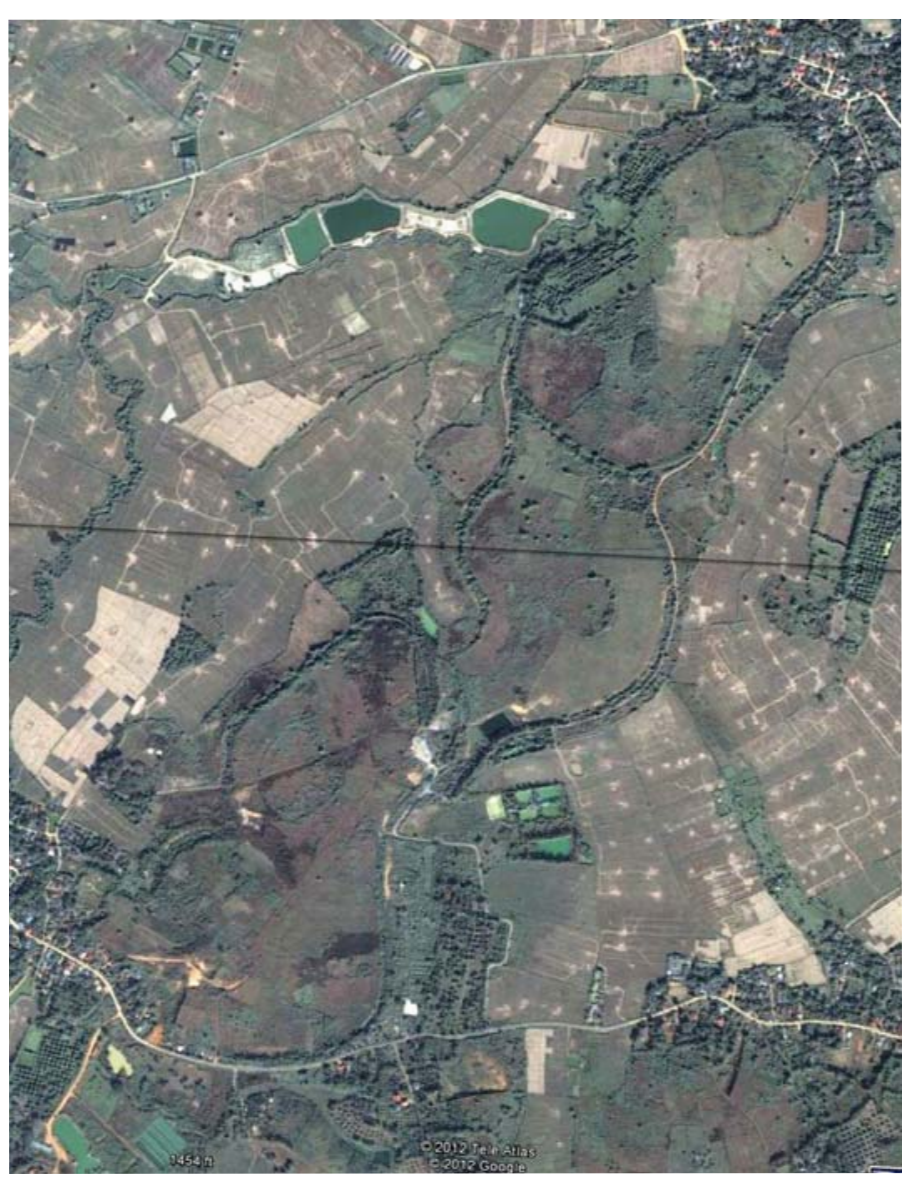

W

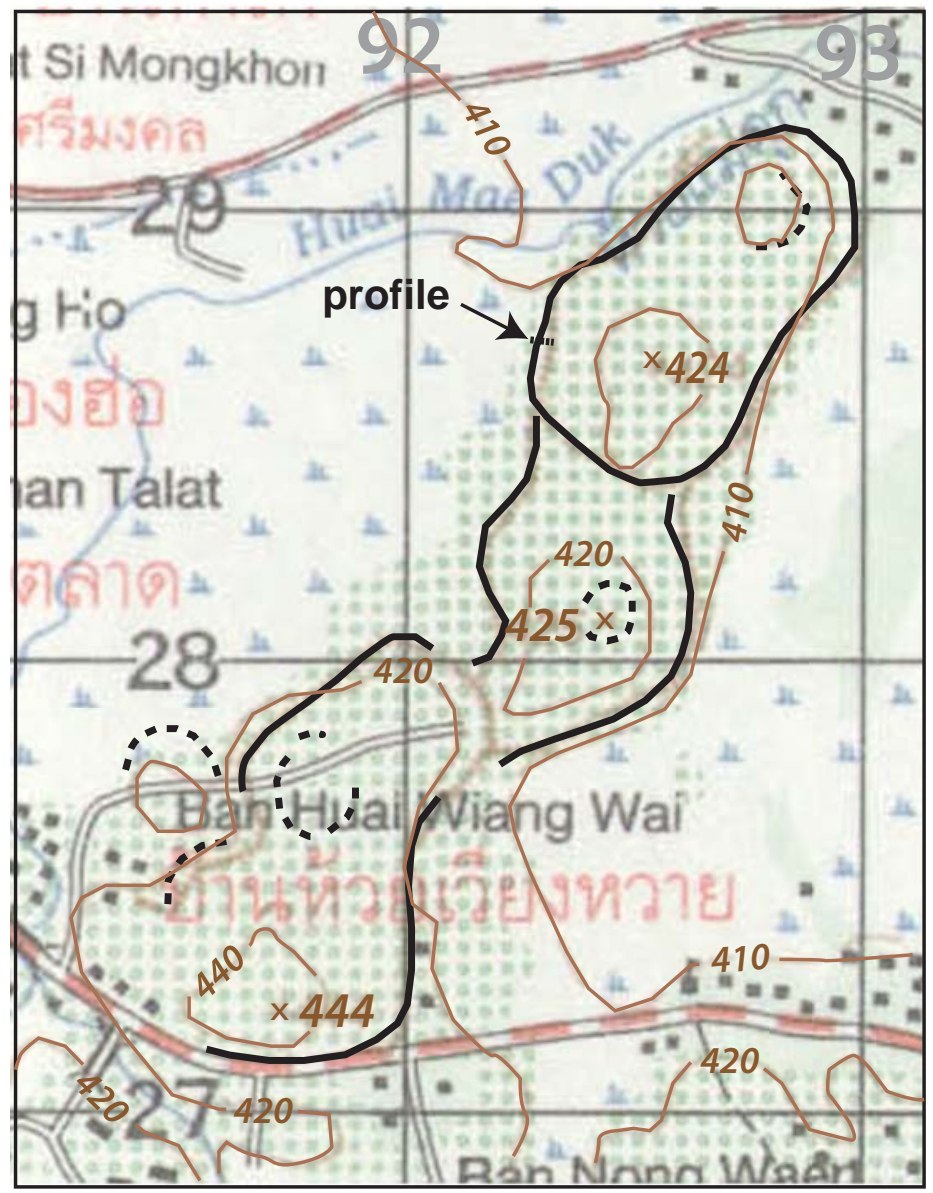

$\mathrm{E}$

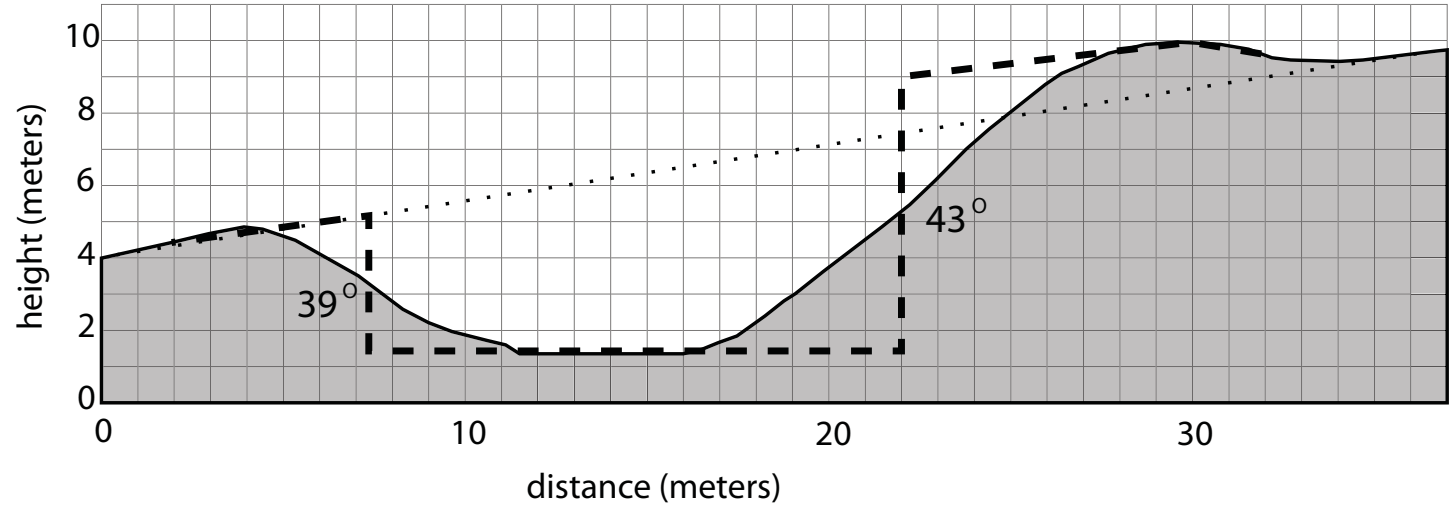

FIGURE 6 -Wiang Wai 

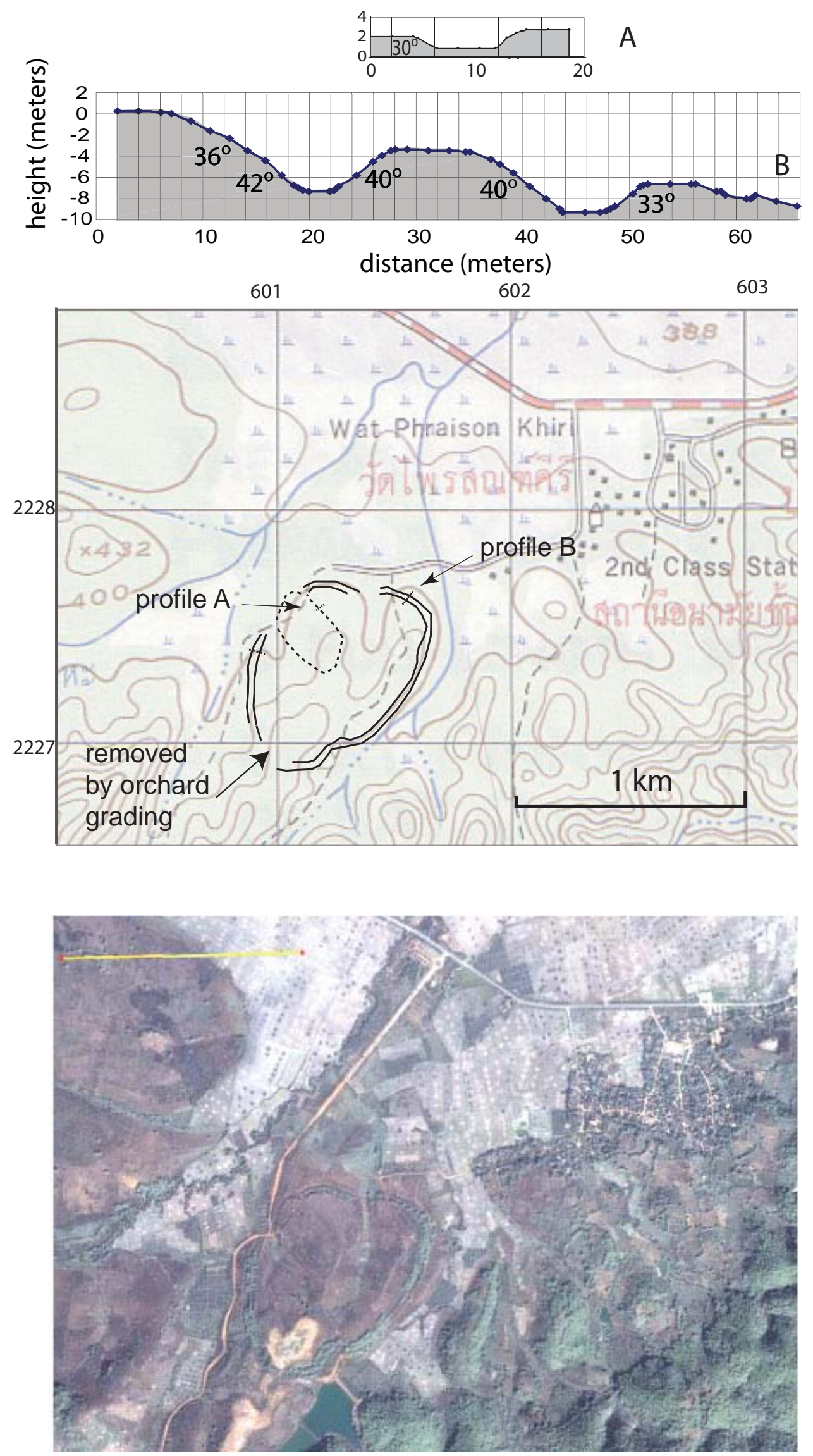
This is an author-produced, peer-reviewed version of this article. The final, definitive version of this document can be found online at Journal of Field Archaeology, published by Maney Publishing. Copyright restrictions may apply. doi: 10.1080/00934690.2015.1103645

\section{$\mathrm{S}$}

$\mathrm{N}$
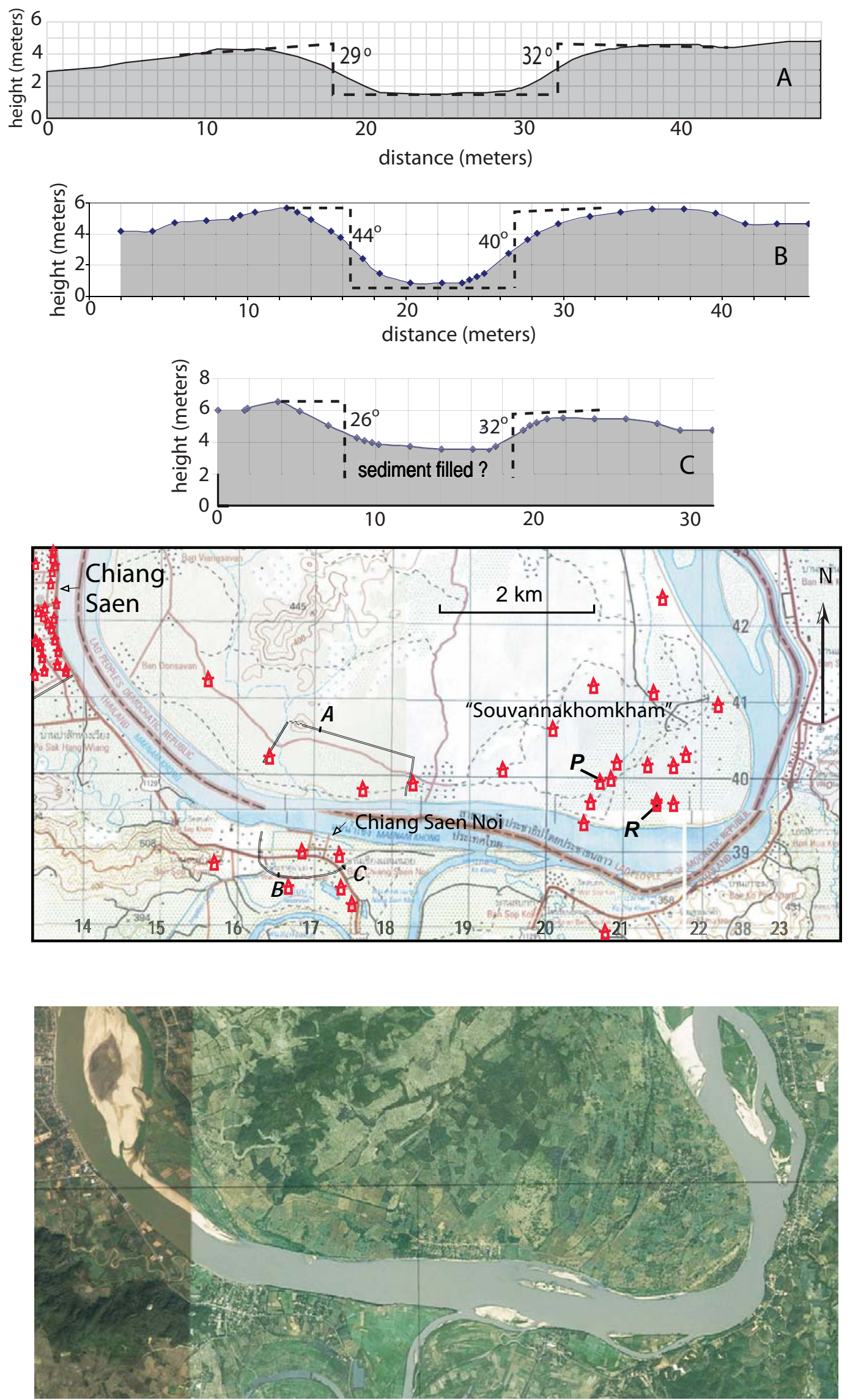

FIGURE 8 
This is an author-produced, peer-reviewed version of this article. The final, definitive version of this document can be found online at Journal of Field Archaeology, published by Maney Publishing. Copyright restrictions may apply. doi: 10.1080/00934690.2015.1103645
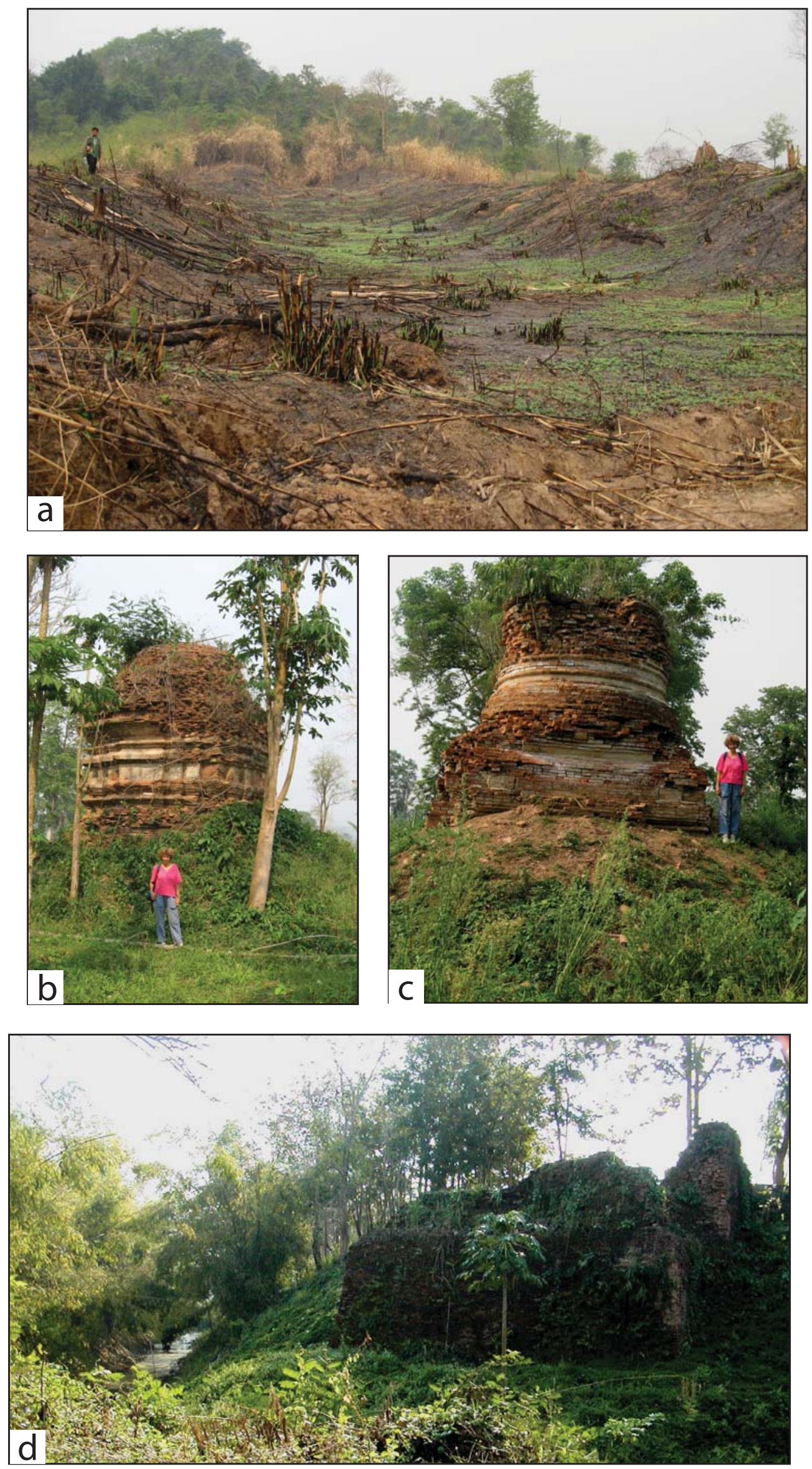
This is an author-produced, peer-reviewed version of this article. The final, definitive version of this document can be found online at Journal of Field Archaeology, published by Maney Publishing. Copyright restrictions may apply. doi: 10.1080/00934690.2015.1103645

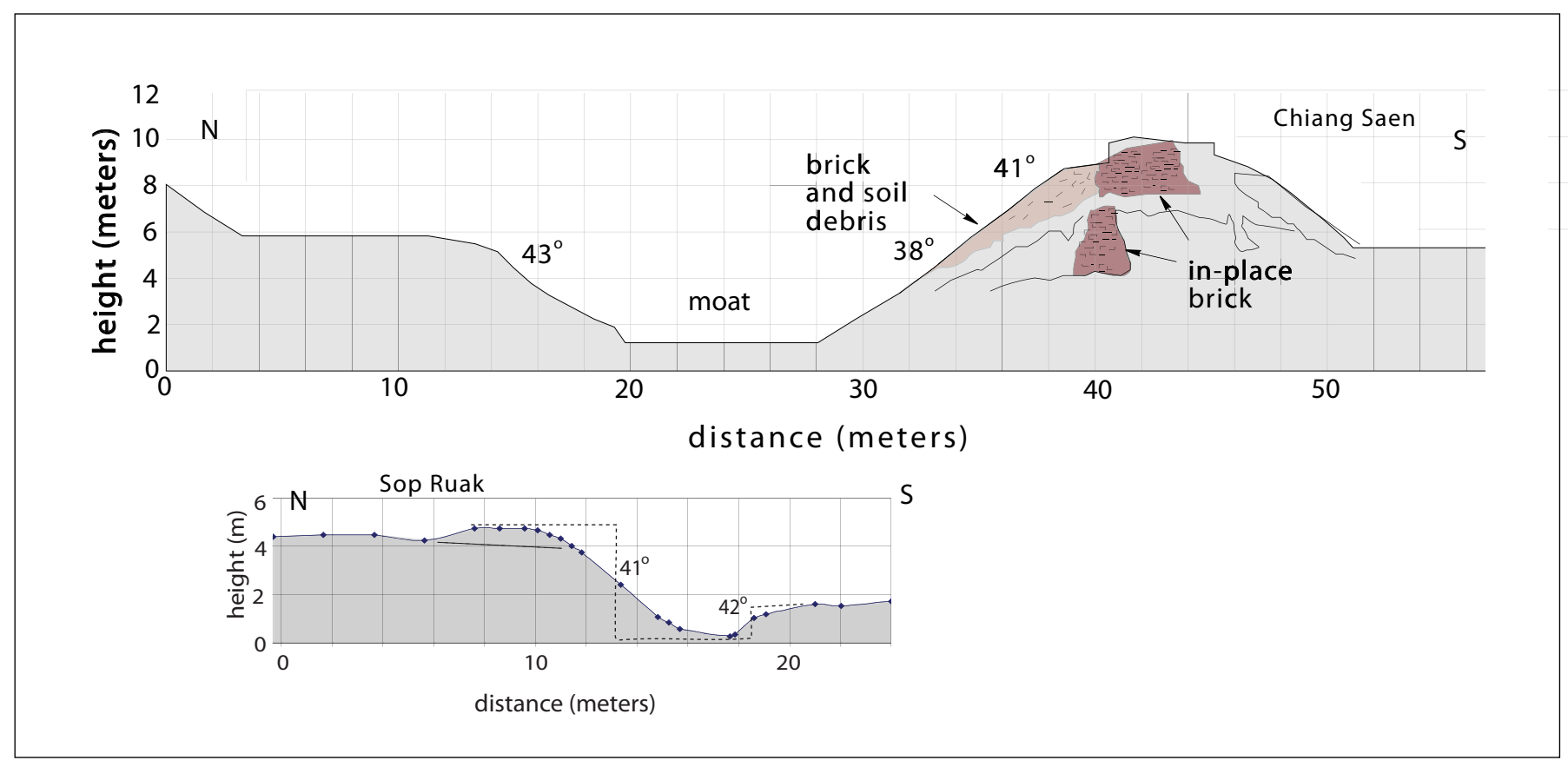

FIGURE 10 -Chiang Saen Wall \& Sop Ruak profiles 


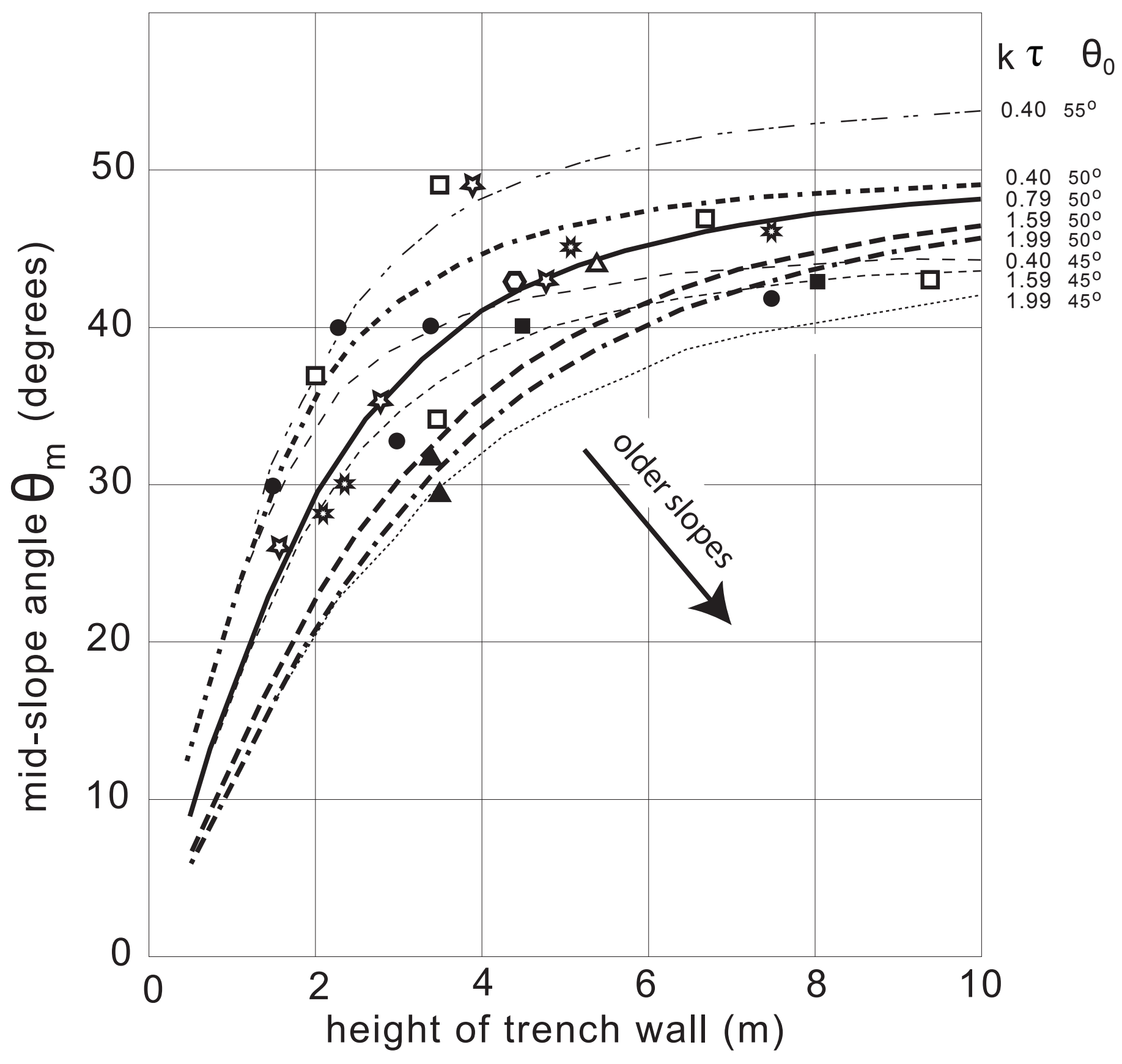

* Phrao, profile A

* Phrao, profile B

- Wiang Wai

- Wat Phraison Kiri
- Chiang Saen moat

$\Delta$ Chiang Saen Noi

ㅁ Ban Nong Pung

A Souvannakhomkham, Laos PDR 

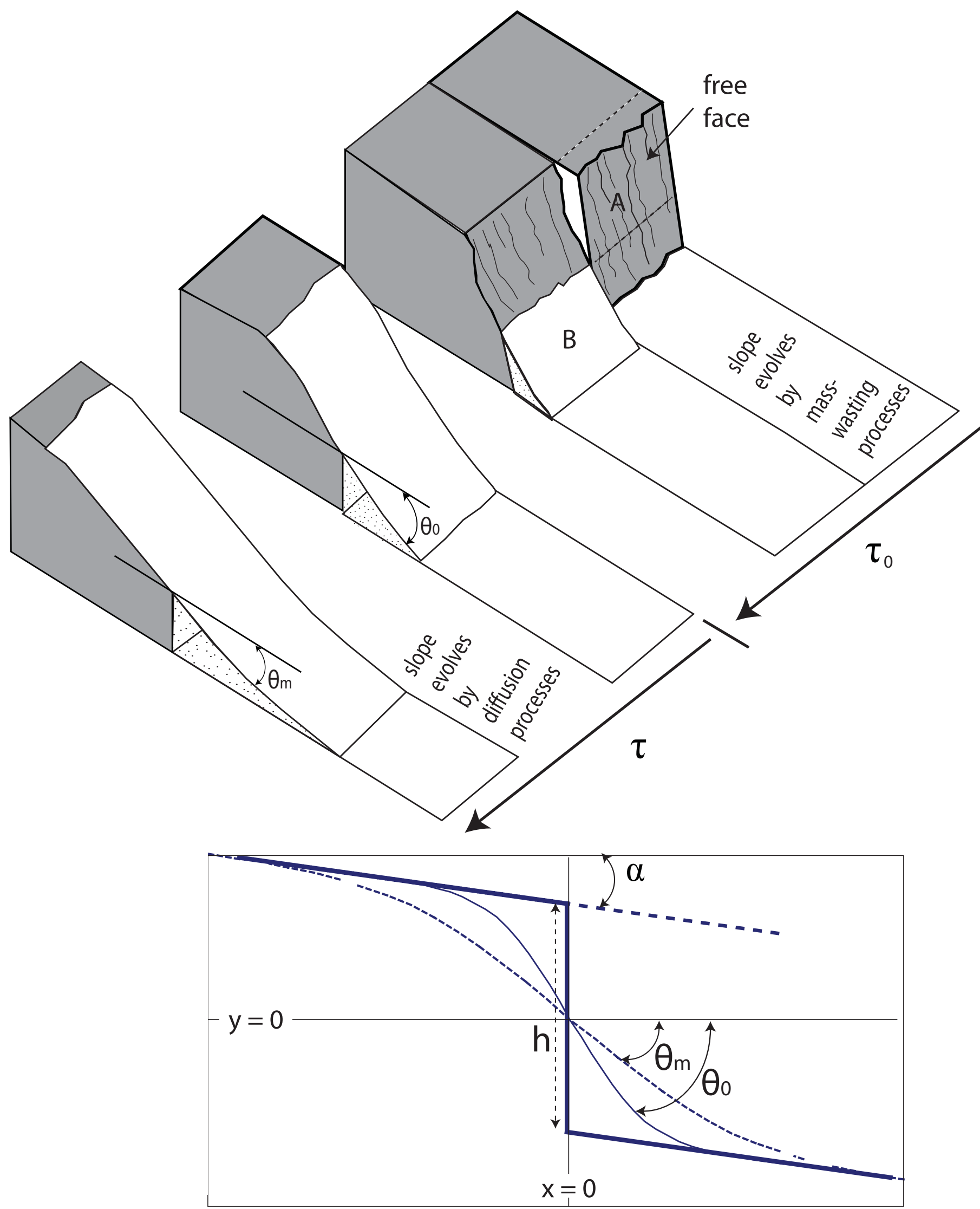